\title{
Factors Affecting Online Purchase Intention of Gen $Y$ in Klang Valley, Malaysia
}

Jee Fenn Chung, Akram Abdulraqeb Sultan Al-Khaled

To Link this Article: http://dx.doi.org/10.6007/IJARBSS/v11-i4/9767

DOI:10.6007/IJARBSS/v11-i4/9767

Received: 05 February 2021, Revised: 10 March 2021, Accepted: 30 March 2021

Published Online: 23 April 2021

In-Text Citation: (Chung \& Al-Khaled, 2021)

To Cite this Article: Chung, J. F., \& Al-Khaled, A. A. S. (2021). Factors Affecting Online Purchase Intention of Gen $\mathrm{Y}$ in Klang Valley, Malaysia. International Journal of Academic Research in Business and Social Sciences, 11(4), 983-1034.

Copyright: (c) 2021 The Author(s)

Published by Human Resource Management Academic Research Society (www.hrmars.com)

This article is published under the Creative Commons Attribution (CC BY 4.0) license. Anyone may reproduce, distribute, translate and create derivative works of this article (for both commercial and non-commercial purposes), subject to full attribution to the original publication and authors. The full terms of this license may be seen

at: http://creativecommons.org/licences/by/4.0/legalcode

$$
\text { Vol. 11, No. 4, 2021, Pg. } 983 \text { - } 1034
$$

Full Terms \& Conditions of access and use can be found at http://hrmars.com/index.php/pages/detail/publication-ethics 


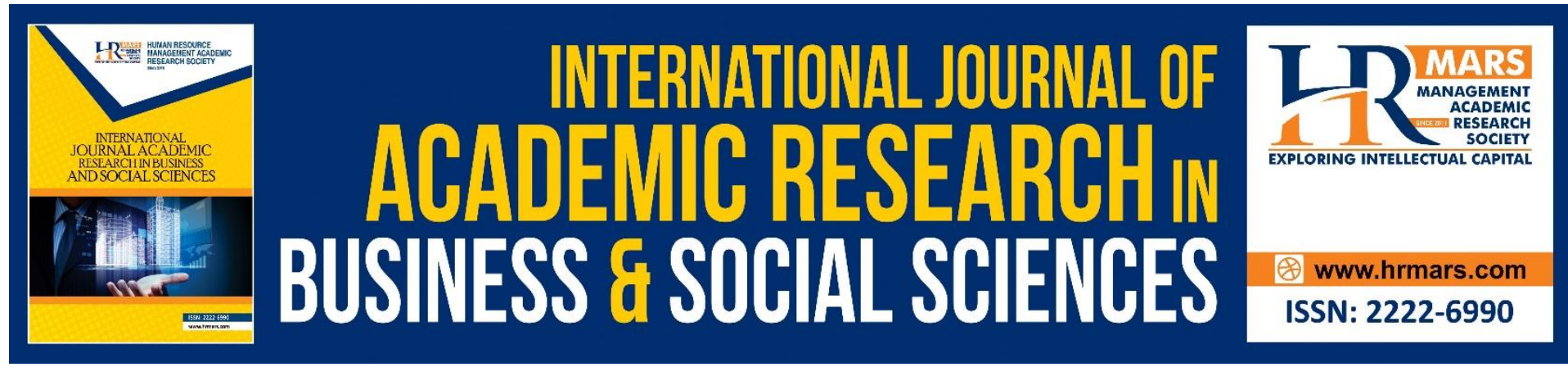

\title{
Factors Affecting Online Purchase Intention of Gen $Y$ in Klang Valley, Malaysia
}

\section{Jee Fenn Chung, PhD, Akram Abdulraqeb Sultan Al-Khaled, PhD}

Associate Professor and Dean of Faculty of Business, Berjaya University College, Malaysia, Senior Lecturer/ Head of MBA Programme, Faculty of Business, Berjaya University College, Malaysia.

Email: chung.jeefenn@berjaya.edu.my

\begin{abstract}
The growing usage of internet and online shopping in Klang Valley Malaysia presents a huge prospect in e-commerce market, especially online shopping. Among all generation, Generation $Y$ is most active in online purchase when compared to other generations. With the help of technology, the choices of consumers have dramatically increased and having access to information through internet makes it easier to make purchasing decisions. The factors that are believed to influence generation y's purchase intention fall into three main categories which are e-satisfaction, brand involvement and technology. The target respondents in the study were aged between 18-36 years old. This study employed a quantitative method and an average of 403 self-administrated questionnaire was distributed through online channel. As a result, electronic satisfaction (e-Satisfaction), brand involvement and technology become vital for online retailers to attract and retain online shoppers in this virtual environment. The association between ESAT, PI and technology should be continuously examined to cope with the advancement in information and communication technology, and the changing expectation of online shoppers. 403 sets of completed and usable questionnaires were gathered using online questionnaire and convenience sampling procedure. The shoppers e-Satisfaction, Brand involvement and technology was positively and significantly affected online purchase intention of generation y. The primary objective of this study was to identify the nature and significance of the relationship between esatisfaction, brand involvement, technology and purchase intention. The specific objectives of the study were to determine the dimensions of e-satisfaction, brand involvement, technology that influence purchase intention of generation $y$. The research hypotheses were derived from the research objectives. A positivist paradigm guided the study. A cross sectional sample survey was used to collect data from stratified randomly selected respondents. Result of findings were concluded in the end of this study, limitation and recommendations for future researches were also included.
\end{abstract}

Keywords: E-satisfaction, Brand Involvement, Technology, Online Purchase Intention. 


\section{Introduction}

Shopping is a popular activity in our daily life, and with the improvement of technology, we can select and purchase products through different vendors, rather than waiting in a long queue in the shopping mall. Doing online shopping is becoming a fashionable trend among people, and young people like operate their own website and pages to provide online services and display products. "Sell and buy" is an old concept, which can be described the behavior when doing e-commerce. The purpose of this study is to examine the factors influencing the intention to purchase online products in Klang Valley from Generation Y. Traditional shopping, online shopping, background of study, problem statement, research goals and research issues will be discussed in this chapter. Then followed by the hypothesis development, theoretical framework and significance of the studies will be discussed as well. In the end of this chapter, a brief description of this chapter will be provided.

\section{Background of Study}

Generation $Y$

Generation $Y$ is large group of young people, born between early 1980s and middle 1990s (San et al.,2015), has attracted much attention due to not only their significant spending power but different shopping behaviours from the other generation. Generation $Y$ have strong perception in making own decision since they are well-educated with advanced technology and information. They are independent and self-absorbed person, sensitive to new social trend and self-expressed (Williams et al 2014). In addition, their consumption pattern is always affected by entertainments such as the television, movie, extreme sport, advertising and internet. Comparing to previous generation, Generation Y prefer in trying new things, switching shopping pattern frequently and always spending effort to build up their personal image. (Williams et al 2015). Millennials have been exposed to the Internet from a very young age and that feature distinguishes them most from other generational cohorts (Bolton et al., 2014). Moreover, the Internet is an essential part of their everyday life (Issa and Isaias, 2016). This age group is often referred to as Generation Y, which has a nick name as "echo boomers" because it is the second largest generation after the baby boomer (19461964) (El-Adly et al, 2016). However, Generation Y (GenY) is a cohort born after Generation $X$ (San et al., 2015) roughly between 1980 and 2000 (Cavagnaro et al., 2018); some put the period between 1978 and 1994 (San et al., 2015; Skinner et al., 2018) or even 1980 and 1994 (Thambiah et al., 2015; Singhi and Monaco et al, 2018). They are also referred to the millennials (Monaco,2018), dot.com generation, echo boomers and millionaires (San et al., 2015). Generation $Y$ is the important in retail area because its shopping behaviours influence all product categories of software and hardware products (Brown, 2015). According to the Parment's study (2014), Generation Y consumers love to spend time at the retail stores looking new products even though they do not have an intention to buy. They usually look for a reasonable price product for themselves.

However, sometimes, the price of product is not an important factor to Generation $Y$ consumers if they really want to have it. They prefer to buy the well-known brand products. The Generation $Y$ consumer segment Due to the heterogeneity of consumer generation lifestyles, the different desires, expectations, experiences, values, preferences, arising mainly from the particularities and specificities of socio-demographic characteristics, from consumer traditions and consumer purchase behaviour, the contemporary society as a whole and also different organizations must think and act according to the principles of' multi-generational marketing'. Such an approach is directed towards establishing proper relations with each 
generation of individuals and succeeding in effectively responding to the needs and behaviours of its members.

The Generation Y segment, also known as Millennials, Dot Net and the iPod Generation, is made up of individuals characterized by multiculturalism, ethnic and sexual tolerance and acceptance. They grew up in an environment dominated by innovation, rapid change, living almost symbiotically with different forms of personal technology e.g. computers, tablets, iPods, etc. A typical Generation $Y$ family has two incomes, individuals rely more on their own forces with a sense of independence and perfect autonomy, being concerned with self-image and relying very much on social networking (Williams and Page, 2014). Generation $Y$ is characterized by the desire to make their own choices, customizing the information received, curiosity and doubt, the spirit of collaboration, speed, entertainment, innovation. Its members are highly educated, mostly being e-learners. The use of email is somewhat out dated for the Generation Y segment; they mostly prefer services such as SMS, social networks; the messages should be short, concise and sincere. The Generation Y segment also uses social media and applications for mobile devices to obtain information about the new products or offers before or during visiting the traditional or the online store, compare other consumers' opinions from online forums about the prior use of products and services and visit blogs to get more information about product characteristics and utility. Whether consumers visit the bricks and mortar or online store to seek information about brands, assortments, products characteristics, functionalities and/ or availability, retailers may benefit depending on their consumption behaviour and their online account available in the retailer's platform, e.g. a customized or special offer, discount coupon, etc. (Fernie and Grant, 2015; Abishek and Hench and, 2016). This strengthens the consumer's general impression about the retailer leading to a purchasing decision much faster than when the client does not know the retailer and their offerings. Further, various social factors (e.g. products used by family and friends, products endorsed by celebrities, etc.) affect their online purchasing behavior (Dhanapal et al., 2015). Generation Y students are an important section of consumers to be studied as they have a specific buying behavior and have positive attitudes towards online shopping. The online fashion stores look at millennials as a very prospective segment because most of the millennial have grown-up with the Internet and are using the Internet for product research and purchasing. Millennials are actually living their lives on the internet. Thus, high purchasing power and a trusted and friendly orientation towards technology, acts as a determining factor for the success of the online retailers. Socialization and feelings of accomplishment also influence the consumption behavior and preferences of members of the Generation Y. Consequently, they are more inclined to the extreme types of buying behavior (Sockwell 2016).

In the case of an online order, the consumer more and more has the option of picking-up the order himself/herself in a traditional store in the neighbourhood of his home or workplace, may visit a collection point of 'drive-in' store if the retailer offers this possibility, or can receive the offer to an established place of destination by courier services (Fernie and Grant, 2015).The young and modern consumer, empowered and enlightened (Dabijia and Grant 2016), is eager to be present everywhere, in any places and with any means, without boundaries, which transforms him into an omni consumer (Yee and Heutger, 2015). Practically, in satisfying his needs, the contemporary consumer is constantly connected with novelties, using when $\mathrm{s} / \mathrm{he}$ uses social networks and other technologies available on portable devices to gain information about the latest offers. He searches information regarding comparison of products, prices etc., and determine the ways through which he might 
optimize the product consumption and utility and increase his or her satisfaction and contentment (Yee and Heutger, 2015). Generation $Y$ will reach $22 \%$ of total population in US in 2030 (MetLife Mature Market Institute, 2014). Generation Y in U.S. is one of the biggest markets with approximately \$1.3 trillion spending power in 2015 (Brown,2015). By2030, this generation will comprise 75 percent of the total global workforce (Naim and Lenkla, 2016; Cavagnaro et al., 2018). Thambiah et al. (2015) reported that Gen $Y$ in Malaysia accounts for 35 percent of the total population and is thus considered the largest segment (San et al., 2015).

Many previous researches deal with the Generation $Y$ online purchase intention (Sepet 2012), and internet shopping behaviors (Arnaudovskate al., 2014; Valentine \& Powers, 2013; Taylor et al 2017). Unlike Generation Y's on-or off-line shopping behaviors, the marketing patterns of the individual subgroup within Generation $Y$ often exhibit the shopping behavior distinct from Generation Y.

Klang Valley

Beginning from $19^{\text {th }}$ century, the development of area happened to expand quickly in the direction of east (Gombak) and westerly (Port Klang) along with urban areas mounting towards the north (Rawang) and south (Negeri Sembilan) (ExpatGo Staff 2014). Although no official borders have been drawn, encompass of the federal territories and several other districts in its vicinity can be considered. These are:

- Federal Territory of Kuala Lumpur

- Federal Territory of Putrajaya

- Selangor District of Petaling

- Selangor District of Klang

- Selangor District of Gombak

- Selangor District of Hulu Langat

Traditional Shopping

You have to leave your home in the conventional shopping, either walk or drive to the supermarket or shopping mall to buy what you want. Conventional shopping enables people to see the actual product before the money is paid by the user. For example, people can try on clothes, check the material, see the design, and know from where does the product comes (Chiu et al 2014). It's a very critical virtual for people buying the products for fashion stuff and fashion clothes because they need to make sure the goods are in the right color and size. It is safer for the consumer compared to online shopping. Besides, traditional shopping also ensures that the consumer can get the product after paying the money. However, it has to spend a lot time and must wait for a free dressing room to try on the clothes etc.

The role of traditional shop in consumers' lifestyles is significant and has changed over time from selling needed products to providing one-stop convenience shopping and entertainment to increasingly more empowered, sophisticated and demanding consumers. As such, shopping mall management and marketers are compelled to continuously develop marketing strategies, to meet the changing consumer demand in order to retain current and attract new customers. Shopping malls are the most recognised site for traditional shopping and are characterised as a distinct type of shopping environment where people engage in buying as well as activities, such as socialising with friends. As a result, leisure and entertainment 
opportunities at shopping malls/traditional shopping have increased significantly (Moolman, 2014). Therefore, food courts, restaurants, theatres, children's play areas, exhibition zones, recreation and meeting spaces are fulfilling the role of anchor tenants in shopping malls (Martin \& Turley, 2014).

Consumers' shopping motivations are a distinct form of consumer behaviour and often differ significantly from one individual to another; hence, two consumers can have different motives for shopping at the same store. Consumers shop for various reasons, such as seeking the best value for money, socialising, escaping from the routine of daily life (Tiwari \& Abraham, 2014), the influence of individual and psychological consumer characteristics (Hinson et al., 2014), cultural (Dhurup, 2015), social and environmental influences, promotional strategies (Hinson et al., 2014), as well as for experiential and emotional reasons (Singh 2015). Notably, Tiwari and Abraham (2014) point out that, while consumers visit shopping malls for different reasons, they all expect an exceptional experience from traditional shopping. According to Wakefield and Baker (2012), aesthetic stimulation pertains to the architectural and interior design of the mall, including the layout and the design features, such as high ceilings, the use of colours and music attract to generation y. Escape activity entails getting away from the demands and stress at work or home (Leong et al 2015). Shopping convenience refers to the mall's operating hours, the location of the mall and the expansive assortments of products and stores to facilitate one-stop shopping (Tiwari \& Abraham, 2014).

The considerable size of the Generation $Y$ market segment renders them important to marketers as well as those engaged in marketing shopping malls (Mitchell et al 2015). Compared to previous generations, Generation $Y$ members have adjusted to a culture of materialism and consumption due to the influence of television and technological innovations (Mitchell et al 2015). The increased role of the media and technology in consumers' lives, such as the threat of internet-based shopping (Ravichandran, 2016), makes strategic planning challenging to the traditional shopping marketer and retailer, especially to those targeting the Generation Y cohort. E-shopping can also have a modifying effect on traditional shopping. In this type of relationship, online shopping alters traditional shopping rather than replacing it. E-shopping can alter the duration of shopping trip, the mode of transport, or destination (hence the distance travelled to make the purchase). For example, before going to a store, buyers can use internet to obtain necessary information regarding their desired product and store. In this case, the traditional trips to stores remain unchanged, but buyers commit less time to browsing and purchasing because they already have access to a good portion of information necessary to make a decision, and this leads to decreased duration of shopping trip. Consumers who choose in-store shopping over the online shopping is because they think that they will be cheated by the seller. It is because there are scammers who are placing fake products or products which are unworthy of the price in this situation the traditional in-store shopping is advantageous than online shopping (Tseng S.Y 2016).

Online Shopping

Online shopping is the activity or action of buying products or services over the Internet. It means going online, landing on a seller's website, selecting something, and arranging for its delivery. The buyer either pays for the good or service online with a credit or debit card or upon delivery (Market Business News 2020). According to OxfordDictionaries.com, online shopping is "The action or activity of buying goods or services over the Internet." 
Remarkable development of the computer technology with communication network evokes the global system of interconnected computer networks, so called "internet". The internet provides a fascinating virtual place for gathering any product and service information, comparing brands, making a choice, and buying (Tang et al, 2016). Many consumers search for product and service information on the internet before they make purchasing decisions. The internet shopping becomes one of the most familiar shopping tools to all generation. In the recent years, there has been a considerable growth in online shopping by internet shoppers due to its great advantages such as convenience, low-price, and diversity. Internet shoppers are convenience and variety seekers who are more innovative and impulsive than non-internet shoppers (Bachledo, 2014). Interestingly, these internet shoppers are usually younger than non-internet shoppers (Jones \& Fox, 2014). For example, most college students easily access the internet owing to their own computer. This young people can search useful information on the internet 5 times faster than the old generation. Their intimate relation with the internet provides more chance to shop for whatever they need on the internet. Transportation limitation of college students who do not have their own car also increases the chance of the internet shopping which offers almost anything they want. Therefore, as a promising internet shopper, it is important to understand internet shopping behaviours of this young generation. According to the statistics, $25 \%$ of consumers like to interact with brands, because they want to join the brand fans' community to get the newest information or discounts. Online community allows consumers to communicate with other consumers or organizations, and it provide a platform where consumers can share experiences and comments on the community. According to the feedbacks and comments on the community, retailers can improve online shop (Salesforce blog, 2015). The search for shopping opportunities is illustrated by a possibility of comparing prices, group purchases (SempruchKrzemińska, 2014) or using promotional coupons. The use of promotional coupons and e-mail offers at traditional retail is a relatively new phenomenon as well (increase of this activity from 25\% to $40 \%$ of declarations in 2015 and 2016, respectively). The consumers using discount coupons are called Promo Hunters (Szulkowski, 2016). The importance of social media can be particularly observed during the consumers' selection of new products and/or brands, and affects the representatives of the $\mathrm{Y}$ generation and Baby Boomers stronger (Epsilon, 2015).

E-commerce today obtains so much prestige because technology offers a platform on the website. People can scan the shape, size of product online, and just make an order. They can select the shipping method and check the delivery phase, rather than spend all day in the shopping mall. Besides the standard/traditional way of shopping, customers can immediately order goods at an online store. Interactive screens are placed at the outlet and allow consumers to make transactions. Afterwards, the ordered goods can be delivered to the chosen address, or they can be sent directly to a parcel locker located in front of the store (Bełcik, 2017). People who are working long hours or those who have very little free time, do not have enough time to go for shopping such as house wives, people who are sick and unable to go to the store find internet shopping more convenient. Internet shopping helps these people to save time and effort. Also, since internet is 24 hours accessible, comparing to the traditional shopping, this becomes one the main drive to go for online shopping.

To most customers main attributes of online shopping are convenience and ease of access (Rana et al 2017). Some consumers like to do online shopping because it allows them to look for information about the product or service available in different websites or different brands. Therefore, consumers can compare and contrast the price or feature differences to 
make best choice for them. When consumers doing online shopping, they will have an opportunity to read through the other customer reviews regarding to the product before making the decision. While, the traditional in-store shopping cannot provide customer reviews. This is the one of the online shopping benefits to the consumers. There are some luxury products being sold on the websites. However, there are still some problems, like quality issues and size problems. It seems that e-commerce has a long way go to replace the physical store, but it still has chance to achieve that in future. E-commerce today reflects demands of consumers and is meant for people (Ecommerce-land 2017)

\section{Top 10 Countries, Ranked by Retail Ecommerce Sales Growth, 2019 $\%$ change}

\section{Mexico}

\section{Malaysia}

6. Canada

7. Indonesia

8. Argentina

9. Russia

\section{South Korea}

\section{$22.4 \%$}

\section{$21.1 \%$}

\section{$20.6 \%$}

\section{Worldwide $20.7 \%$}

Note: includes products or services ordered using the internet via any device, regardless of the method of payment or fulfillment; excludes travel and event tickets, payments such as bill pay, taxes or money transfers, food services and drinking place sales, gambling and other vice good sales Source: eMarketer, May 2019

Figure 1.0: Global comparison revenue

(Source from eMarketer 2019) 


\section{Problem Statement}

Plenty of companies have transformed or expanded their businesses from traditional physical stores to online stores to focus on transactions of commodities or services through electronic systems such as internet and other computer networks (Ordun, 2015). As a matter of fact, ecommerce in Malaysia is still evolving from the current prototype. Decoding and understanding the online consumer behavior is much more complicated than decoding traditional consumer behavior due to zero physical interaction during the transactions (Jiang, Chen, \& Wang, 2008). Ramayah and Ignatius (2010) also state similar statement, it is crucial for ecommerce business to be effective in managing customer service relationship due to no human interaction during the transaction.

According Wedayanti and Giantari (2016), subjective norms refer to the opinion given by someone who has close relationship with the individual, such as friend, peer or family who advise the individual to perform or not perform certain behaviors and motivation accompanied by a willingness to do or not do something that was considered important. The underlying assumption is that individuals tend to consult their social network about new technologies and can be influenced by perceived social pressure of important others (Slade et al., 2015).

The authors have come across some research studied on Millennial online purchasing behavior like one of the studies has shown a significant relationship among the age and purchasing items which are endorsed by celebrities (Sethi et al., 2018). It was found in this study that Millennial consumers were more likely to purchase items which were endorsed by celebrities on social media channels like Facebook and Twitter. This study pertained to the social media sites and not specifically to the online stores as studied in this paper. As discussed above we can see that there is some of the past research that elaborates the factors that affect online shopping.

However, there are only few researches done by Factors affecting online purchase intention in southeast Asia. Weng (2018) discussed that website quality social activities and online purchase intention in China; Chiang (2018) talks about Experiential Value affects Purchase Intentions for Online-to-Offline Goods: Consumer Feedback as a Mediator. Nisha Gupta and Rajiv Jain (2017) in their study titled "Consumer Behaviour towards E-Commerce: Online Shopping in India" identified that there are major security concerns in online transactions and at present people do not feel comfortable doing the shopping online. They feel that there are high risks of fraud and hoax in online business. According to Manish Kumar (2016) in his study provides some useful insights on consumers' purchasing intention and behaviour. It has been revealed that the three key factors, i.e., price, ratings, and reviews affect the consumers' intention for online shopping. Tsitsika \& Janikian, (2014) concluded from their study that internet continues to grow beyond our belief. Nearly $32.7 \%$ of the world's population has access to the social networking sites like Face book, Twitter, Linked-In, YouTube, Flicker, blogs, etc. which allows people to rapidly share their interests of the moment with others everywhere. So, the interconnectedness throughout the world is growing rapidly due to internet use. According to Pavlina, Vojtech (2017) Factors affecting Generation Y Customers' Satisfaction with Online Group-Buying Purchases in South Korea. It concludes that South Korean Generation Y consumers' behaviour in the online group buying. The factors Perceived Value and Website Quality are indicators that influence the consumers' confirmation that has the effect on the customers' satisfaction.

However, studies have also been conducted in the same field such as a study by Monsuwe, Dellaert \& de Ruyter (2014) which looked to explore what drove consumers to shop online in 
the Setiowati et al (2018) conducting a Europe based study explaining the role of customer purchase intention with factors like equity and value, service quality, loyalty, switching cost and brand preference. Rahman (2015) 'Is Generation Y addicted to social media?' found in his study that generation- $Y$ i.e. the present generation is psychologically addicted to the social Medias like face book, Twitter, Linked In etc. This addiction towards media is responsible for intra-psychic conflicts such as intolerance and relapse among the youth.

However, in Malaysia has only few researches studied by purchase intention in Generation Y. according to Xiao, Yang and Iqbal (2018) referred to the Factors Affecting Purchase Intentions in Generation Y: An Empirical Evidence from Fast Food Industry in Malaysia, Chi et al (2014) Factors influencing Generation Y's online purchase intention in book industry, Hussein (2016) Assessing the Purchase intention of Malaysian Generation $Y$ in mobile shopping.

Moreover, some of the mentioned studies have not been carried out in the context of Millennials purchase intention specifically for online shopping research. Thus, most of the studies have focused more on the effect of trust, perceived risk, perceived value and consumer behavior but still lack of understanding the subject matter that has potential to impact generation y consumers shopping intention. The online purchasing patterns cannot be compared with other developed countries hence this study can be helpful in understanding the intentions of the users in Klang valley Malaysia. In this study we will looking into purchase intention with independent variables like e-satisfaction, brand involvement, technology with moderating factor as location. These modern variables are going to be discussed in relationship to purchasing online shopping of generation $y$ in Klang valley, it will help contribute and understand to the online purchase intention of generation y. Previous studies examined the five variables in isolation or in pairs, this study adopted an integrated approach and sought to establish the influence of purchase intention of Generation Y. The study sought answers to the research question, 'what was the nature of relationship between esatisfaction, brand involvement, technology and location amongst Purchase intention in Generation Y?'

\section{Research Questions and Research Objectives Research Questions}

In this study, find answers to the following questions:

1. Is E-Satisfaction influence online purchase intention of Generation Y?

2. Is Brand Involvement influence online purchase intention of Generation Y?

3. Is Technology influence online purchase intention of Generation Y?

4. Is the moderating effect of Location affect the relationship between ESatisfaction and Purchase intention?

5. Is the moderating effect of Location affect the relationship between Brand involvement and Purchase intention?

6. Is the moderating effect of Location affect the relationship between Technology and Purchase intention?

\section{Research Objectives}

1. To examine the influence of E-Satisfaction towards Online purchase intention of Generation $Y$

2. To examine the influence of Brand involvement towards Online purchase intention of Generation Y 
3. To examine the influence of Technology towards Online purchase intention of Generation $Y$

4. To examine the moderating effect of Location, affect the relationship between ESatisfaction and Purchase intention.

5. To examine the moderating effect of Location, affect the relationship between Brand involvement and Purchase intention.

6. To examine the moderating effect of Location, affect the relationship between Technology and Purchase intention.

\section{Significant of Study}

Internet technology is updating rapidly to the extent where shopping is made possible through the Internet. Therefore, consumers can easily acquire products or services without leaving their home and with hassle free. However, it is difficult to establish or maintain a good relationship between the online sellers and buyers because both parties do not have physical contact with each other. From the consumers' point of view, consumers able to get more concern from marketer with the e-satisfaction, brand involvement and technology. Thus, consumers will feel fun and pleasure when shop online meanwhile feel secure too when doing payment or transaction via internet.

Moreover, this study also can create a valuable reference to researchers. For future research, researchers can use other type of methodologies such as quantitative method to examine the e-satisfaction, brand involvement technology and purchase intention. Besides that, researchers have a better understanding and knowledge on generation y's consumer purchase decision making on online apparel retailing. Therefore, researchers may replicate similar studies involving online shopper and find out the difference in different industry or area. Products or fashion consists a very large market share and considered one of the largest e-commerce categories. However, very limited studies focus on online shopping industry in Malaysia. Therefore, this study is conducted in Klang Valley Malaysia in attempts to fill the gap on Klang valley Generation Y consumers' e-satisfaction, brand involvement, technology and purchase intention and contribute useful information on the Klang valley generation $y$ consumers' online purchase intention.

Therefore, the significance of this study is to help the online retailers in identifying the reasons that drive Generation $Y$ to use Internet as a medium in purchasing online. The outcome of this study will be served as guidance for online retailers about factors that they should take into account in order to improve their business performance. By leveraging these factors, they will be able to retain those existing customers as well as to attract new or potential customers in future.

Furthermore, this study might also help the online retailers to build their competitive advantages against potential competitors. As mentioned earlier, there are large number of Internet users who intended to purchase online in future. In such profitable market, there will be a large number of online retailers who are interested to enter into this market. Thus, the research outcome allows them to have a clearer insight and to develop efficient and effective strategies. Thus, the online retailers are able to meet customers 'expectation and thus enhance their loyalty. As a result, the potential competitors will have difficulties in taking over the market shares. Products can be easily acquired without consumers leaving their home. However, it is difficult for online retailers to determine the crucial and significant factors that are valued by the consumers. This study is to help the online retailers in determining the 
reasoning that drive Generation Y's purchase intention on online shopping of products (Yong et al., 2014).

Thus, government also can use the information from this study to build Malaysia's vibrancy as a profitable market for online shopping. Malaysia's e-commerce market size and share will grow exponentially. Saying that, continued efforts to boost internet penetration and advanced logistics are also crucial elements to hike the development of e-commerce in Malaysia (The star online 2015).

This research will provide a broad picture on the perception of Generation $Y$ on how to online shopping improve their customer satisfaction, service and security in the future.

\section{Literature Review}

Chapter Introduction

This chapter begins with an assessment of the other article as well as studies connected to the research topic by outlining the independent and dependent variables temporarily. The purpose of this chapter is to selectively refer to some of the journals with a stronger understanding of the purchase intention of the generation $y$, independent and dependent variable, and to outline previous research findings on factors affecting online purchase intention of $y$.

Theoretical background

Technology accepting model (TAM)

A website is a product of an information technology, as such, online purchase intention should be explained as part of the Technology Acceptance Model (TAM). The TAM was first developed by Davis to clarify the user response of the technology in the working environment (Davis 1989). The model suggests that based on certain beliefs, a person frames an attitude to a specific object, on the premise of which he/she shapes an intention to behave with respect to that object. Therefore, the intention to behave is the major element of the actual behavior. Davis formulated the model based on the Theory of Reasoned Action (TRA), by specifying two key beliefs that specifically explain of technology usage. The original TAM model is empirically validated in a variety of settings, specifically in the context of Internet usage and website usage. By considering the online shopper as a computer user and by treating the web store as a technology system, TAM has been used to test user intention to use the web store (Koufaris 2002). Indeed, online shoppers need to cooperate with technology to purchase the goods and services they need. Theoretical base of Expectation-Confirmation Model and trust According to Oliver (1999), satisfaction is defined as the psychological condition based on the difference between consumers' expectation and actual satisfaction measured after a purchase. If we measure satisfaction from the customers' perspective, we can use customers' perception about each factor creating contributing to the satisfaction. However, it is not only important to know the perception of each attribute. It is equally important to determine which indicators have the significant impact on the global assessment of the purchase (de Oña et al., 2013). Marketing specialists usually ask customers to express their opinions about the importance of each satisfaction's indicator directly, but this approach could lead to some erroneous estimations. Respondents can rate some indicators as important even though they have little impact on their overall satisfaction, or they are important only in one part of the assessment process (de Oña et al., 2013). To prevent this erroneous estimation, Weinstein (2000) recommends applying one of the derived methods that identify the importance of the indicators by statistically testing the 
strength of the relation of the individual indicators with the overall satisfaction. Shiau and Luo (2012) or Hsu et al. (2015) apply structural equation modelling in order to measure customers' satisfaction. As was mentioned above, this paper applies Expectation-Confirmation Model (ECM) by Oliver (1992) in order to design model of online purchase intention of Generation $Y$ in Klang valley. When the performance is worse than expectations, it leads to bad outcome (disconfirmation or negative discrepancy), while exceeding expectations with performance means positive discrepancy and confirmation.

\section{E-satisfaction}

E-shopping satisfaction is the online consumer response of the judgment that an online product or service feature provided a pleasurable level of consumption related fulfilment ( $\mathrm{Ha}$ \& Stoel, 2014). Anderson and Srinivasan (2016) also defined online satisfaction as the contentment of customer base on prior purchasing experience from e-commerce firm. Customer satisfaction is fundamental aspect of marketing which suggest that satisfying customer needs can generate customer purchase intention (Chang \& Wang, 2014). Based on earlier study of Oliver (1997 as cited in Chang \& Wang, 2014), customer satisfaction referred to consumer reaction and elicit positive or negative feeling about the value of service or product from a retailer. Another study from Chang \& Wang, (2014) described consumer satisfaction as a person feeling of either pleasure or disappointment resulting from judgment of the product or service performance in relation to consumer expectations. Satisfaction is the consequences of consumer experiences during different purchasing stages such need something, information gathering, evaluation of purchase alternatives, purchase intention and post purchase behavior.

The emotional factors of touching and checking as will affect consumer's shopping decision, but online shop does not allow consumer to have the trying part. But how can the online shop become reliable and establish a confidence with consumers? Normally the trust of origin comes from good previous experiences of customers. Online consumer can scan the comments and feedbacks on the websites and the feeling of trust will increase or decrease towards this shop (Canadian Center of Science and Education 2017). The online site needs to provide a clear space customer can search what they want, allow consumers to search for the information they want and to easily make comparisons with similar stores. The online shops give consumers more chances to compare the same product with other websites (Cheng Lu Wang, 2014). In other words, prices are regarded as the primary factor to influence the online consumer satisfaction, and money saving and price comparison are two attributes of it.

The experiences gained from the online shopping are very important for consumers. The reason is it will affect the consumer's perception to continue to shop online. Consumers will make specific evaluations, such as given information about the product, privacy, security, form of payment, how he delivery terms work, what are the risks that consumers will be facing, when the items delivered to the consumers, if the products are satisfactory (Parasuraman and Krishnan, 2015). According to the Shabib \& Ganguli (2017) if the online shopping experiences resulted satisfactory to the consumers, the outcome leads consumers to carry on to do online shopping in the future. On the other hand, if the consumers past experiences with the online shopping are unsatisfactory, consumers are hesitant to keep on doing online shopping in the future. Thus, this says that companies to provide fulfilling online shopping experiences to keep their existing customers, so that customers will shop on the internet repeatedly. 
Moreover, measuring degree of customer satisfaction is important for online retailer due to customer satisfaction able to influence consumer purchase decision (Lin \& Sun, 2014). Research by Schaupp and Belanger (2019) also indicated that consumer satisfaction is important and critical to establish long term client relationship which significantly sustaining profitability of business. Therefore, retailers have to ensure products or services meet the expectation of the consumers as satisfied customers are likely make repetitive purchase which increase profitability of e-commerce firm (Jiradilok et al., 2014). Purchase intention promotes more profitable businesses to the industry, particularly when customers are satisfied with the production. Hence, purchase intention has been regarded as one of the most significant sections in the business field. Generally, customer satisfaction is described as how customers assess production after utilizing a product as well as how they estimate the services of production by comparing it with products from other companies that are in the same industry. On another note, purchase intention is responsible in determining if a product meets customers' expectations and need in order to further explore their assessment on goods and services. This notion claims that customers will be more satisfied when the field of production and services meets the customers' expectations. On the other hand, customers will be more dissatisfied if the performance of production is less than their expectations. More importantly, purchase intention is the key to promote a long-term business success which helps to keep customers and collect CLV (customer lifetime value). There is some observed confirmation for a positive association between customer satisfaction and purchase intention. Restated, in the online environment, if customers have received a satisfactory service from services provide rare likely to show positive behavioural intention, leading to increased future purchase intention. Zhang et al (2016) indicated in a study that overall satisfaction of customer with internet self-service technologies (SST) has a positive impact on positive intentions, particularly on willingness to continue purchasing from the same service provider.

Previous shopping experience is also one of the important influential elements on internet shopping (Fang et al., 2016). There are some reports that consumers who have positive previous experiences in internet shopping have greater intentions to repurchase product online in the future (Huang, 2014). When consumers have positive experiences with satisfaction of their product purchased from on-line retailers, they tend to revisit the website for shopping (Fang et al., 2016). Meanwhile, some consumers without any shopping experience on the internet have less intention of internet shopping. For this reason, the impact of the previous internet shopping experience on shopping behaviours can be strong enough to be a key "variable" in internet shopping behaviour. Consumer satisfaction is important to marketers and business owners, because it provides the information so that they can improve and manage their businesses.

$\mathrm{H1}$ : E-Satisfaction has positive influence on online purchase intention of Generation

\section{Hypothesis}

In this study, there are three hypotheses have been developed. These are following:

$\mathrm{HO}$ : There is no significant relationship between E-Satisfaction and online purchase intention of Generation Y

$\mathrm{H} 1$ : There is a significant relationship between E-Satisfaction and online purchase intention of Generation Y 
HO: There is no significant relationship between Brand involvement and online purchase intention of Generation $Y$

$\mathrm{H} 2$ : There is a significant relationship between Brand involvement and online purchase intention of Generation $Y$

H0: There is no significant relationship between Technology acceptance model and online purchase intention of Generation $Y$

H3: There is a significant relationship between Technology acceptance model and online purchase intention of Generation $Y$

HO: Location has not moderating effect on between E-Satisfaction and Purchase intention of Generation $Y$

H4: Location has moderating effect on between E-Satisfaction and Purchase intention of Generation $Y$

H0: Location has not moderating effect on between Brand involvement and Purchase of Generation $\mathrm{Y}$ intention

H5: Location has moderating effect on between Brand involvement and Purchase intention of Generation Y

HO: Location has not moderating effect on between Technology and Purchase intention of Generation $Y$

H6: Location has moderating effect on between Technology and Purchase intention of Generation $Y$

\section{Chapter Summary}

Chapter two has provided detailed literature review on overviewing of study objectives in this research. Therefore, definition of crucial keywords in this study, importance of purchase intention as an influential factor in generation y online shopping. The literature regarding esatisfaction, brand involvement, technology and purchase intention were being reviewed in this chapter. Moreover, the findings and relevant theoretical models of previous researchers are used to support the hypotheses and relationship between those variables and mediator. In next chapter, the explanation of research methodology will be presented in next chapter.

\section{Research Methodolgy}

Introduction

In this research study, this part explains about the research design used as well as the types of approach. Further, the selected type of data collection, target population, sample size, selected sampling method and data analysis method will be covered.

\section{Research Design}

According to Saunders, Lewis and Thornhill (2009), research design will be the general plan of how to answer research question. The research is based on casual research design whereby the cause and effect relationship between the independent variables and dependent variable in a specific situation or problem are studied. Questionnaire with range of questions will be established and distributed via online due to cost plus time constraint.

Primary research

Primary data can be described as the data collected specifically for the research being undertaken (Saunders et al., 2009). In this research study, primary data is collected through the self-administered types of questionnaire. According to Saunders et al. (2009), selfadministered types of questionnaire can be administered electronically using internet, 
delivered by hand to each respondent and collected later or posted to respondents who return them by post after completion. The method of questionnaire administered electronically using internet (Facebook and email) has been selected to obtain the primary data in this research study in order to support the research objectives. The main reason of using electronic survey due to the sample size of this research study is related to online shoppers who had experienced shopping and had purchased apparel from online store.

Sampling population

In this study, the groups of respondents were narrowed down to individuals who have the experience and the intention of purchasing products online. Individuals that age between 18 to 37 years old (San et al.,2015).

This study examines the relationship between three factors namely e-satisfaction, brand involvement and technology with purchase intention of Millennials for online product stores. Klang Valley is also home to about 7.9 million of people or equivalent of more than fifth of the entire Malaysian population of 32.2 million of people (Department of Statistics Malaysia, 2019). This significant number of populations offers good sampling base and also accurate generalizability of results.

\section{Sampling Frame}

The respondents of this study were the Millennials as individuals whom born from the early 1980 s to the mid-1990s. Age between 18-37 who had purchase online shops and shop apparel through online store and can provide evaluation of e-shopping quality dimensions on online apparel stores. Also known as digital natives, millennials are those born between 1980 and 1990 and technology is part of their everyday lives: all their activities are mediated by a screen. The concept of on and off is completely integrated into their lives. However, they were not born into it; they migrated to the digital world from the analogue one in which they were living.

\section{Sampling Technique}

According to Saunders, Lewis and Thornhill (2012), sampling techniques has been segregated into two types which included probability sampling and non-probability sampling. As a type of non-probability sampling, the convenience sampling is selected and used as the sampling technique in the research. Convenience sampling is defined as the collection of information from members of the population who are conveniently available to provide it as mentioned by Kumar et al (2013).

Convenience sampling is selected for this study which is under the category of nonprobability sampling technique. Based on Saunders et al. (2009), non-probability sampling technique is defined as sampling technique that provide a range of techniques to select samples according to personal own subjective judgments. Meanwhile, convenience sampling technique is involved selecting haphazardly those cases that are easiest to obtain for the sample and sample selection process is continued until required sample has been reached (Saunders et al., 2009). By using the convenience sampling technique, researcher able to obtain the sample sizes quickly with the easiest way.

\section{Sampling Size}

According to Krejcie and Morgan (1970), the ever-increasing demand for studies has developed a need for an effective technique to determine the sample size necessary to 
represent a specified population. The target population in Klang Valley estimated to be 7.4 million. Margin of error is 5\%, confidence level of $95 \%$ the sample size of this research will be 384 respondents for the survey result (Survey System.com).

Sample Sizes for Different Sizes of Population at a 95 Confidence level

\begin{tabular}{|c|c|c|c|c|}
\hline \multirow[b]{2}{*}{ Population } & \multicolumn{4}{|c|}{ Margin of Error } \\
\hline & $5 \%$ & $3 \%$ & $2 \%$ & $1 \%$ \\
\hline 50 & 44 & 48 & 49 & 50 \\
\hline 100 & 79 & 91 & 96 & 99 \\
\hline 150 & 108 & 132 & 141 & 148 \\
\hline 200 & 132 & 168 & 185 & 196 \\
\hline 250 & 151 & 203 & 226 & 244 \\
\hline 300 & 168 & 234 & 267 & 291 \\
\hline 400 & 196 & 291 & 343 & 384 \\
\hline 500 & 217 & 340 & 414 & 475 \\
\hline 750 & 254 & 440 & 571 & 696 \\
\hline 1000 & 278 & 516 & 706 & 906 \\
\hline 2000 & 322 & 696 & 1091 & 1655 \\
\hline 5000 & 357 & 879 & 1622 & 3288 \\
\hline 10000 & 370 & 964 & 1936 & 4899 \\
\hline 100000 & 383 & 1056 & 2345 & 8762 \\
\hline 1000000 & 384 & 1066 & 2395 & 9513 \\
\hline 10000000 & 384 & 1067 & 2400 & 9595 \\
\hline
\end{tabular}

Table 3.0: Source from: Saunders, M., Lewis, P., \& Thornhill, A. (2009). Research methods for business students (5th ed.). Prentice Hall: Financial Times.

Data Collection Method

Data is the most important and valuable information for all researches as those collected data from the respondents will be used by the researchers to answer the hypothesis and research questions. In order to collect sufficient data for this study, primary data and secondary data were used to show significant relationship between dependent variable and independent variables.

The researcher is going to use a quantitative method where it will involve the use of questionnaire's through surveys as the main data collection method for this type of research. A questionnaire is a data collection tool that has a set of questions outlined to collect information from respondents. The distribution of these questionnaires will be online in order to acquire the required information. Facilitation of the online questionnaires will be through google forms, online software.

\section{Questionnaire}

The distribution of questionnaire to the respondents has been carried out through an online channel and physical channel in order to acquire the needed information. The online channel involves facilitation of online questionnaire through Google Forms; online software dedicated to creation of surveys and recording of responses. Social networks platforms and online message boards were also the primary outlets in which the online questionnaires were distributed to. As for physical channel, the researcher handed out questionnaires in person to respondents found in the university, rail transport stations and shopping malls. 
Scales of Measurement

A scale of measurement is crucial in a research because it helps to make comparison between the amount of changes occurred in the variables measured. Two out of the four basic measurements of scale are used in this research which is the Nominal scale and Likert scale. Nominal scale

According to Sekaran and Bougie (2016), a nominal scale refers to a scale that allocates subjects to a certain category or groups. For this research, the nominal scale is used to measure age, gender, race, education level, occupation and income level.

\section{Likert Scale}

A Likert scale refers to measurement of scale for attitude or opinion of the respondents according to Sekaran and Bougie (2016). For this research, the questionnaire employed a fivepoint Likert scale whereby the respondents is required to designate their level of agreement or disagreement pertaining to a series of statements concerning perceiver's satisfaction, brand involvement, technology, location and purchase intention amongst Generation $Y$ through choices ranging from Strong Disagree (1) to Strong Agree (5).

\section{Data Processing}

Data processing can be defined as the preparation of data collected for statistical analysis purposes through editing, coding and data entry as mentioned by Kumar et al (2013). For this research, data will collect processing through computer software which is Microsoft excel and IBM SPSS statistic 23.0.

\subsubsection{Pilot test}

The main reason of pilot test is to refine questionnaire that enable respondents do not have any problems when respond to questionnaire meanwhile to obtain some assessment of the questions' validity and reliability of the data (Saunders et al., 2009). Pilot test will be conducted before the actual distribution of questionnaire to the respondents. Moreover, the problem or error at the early stage able to minimize through the pilot test. In this research, a pilot test has been carried out with 40 sample respondents to improve the questions in the questionnaire prior to its official release to ensure the language used and questions asked in the questionnaire is thoroughly understood by the respondents.

Table 3.1: Result of reliability analysis

\begin{tabular}{llcc} 
& Variables & Cronbach's Alpha & Number of items \\
Independent & E-satisfaction & 0.930 & 8 \\
variables & Brand involvement & 0.909 & 7 \\
\multirow{2}{*}{ Moderator } & Technology & 0.908 & 7 \\
\multirow{2}{*}{ Dependent variable } & Location & 0.936 & 7 \\
& & & 7
\end{tabular}

Data Analysis

Normality Test

Normality testing is a technique used for measuring the normal distribution of information in SPSS statistical software. The shape of sample distribution will be compared with shape of 
normal curve (Normality test in SPSS 2016) In this research, the data distribution is analysed using the skewedness and kurtosis measurement.

\section{Reliability Test}

The aim of the reliability analysis is to examine information collection methods and analytical procedures on researchers if they were repeated at another time or replicated by another investigator (Saunders, Lewis and Thornhill, 2012). Participant error here refers to any factor adversely affecting the reaction of the participant; whereas the mistake of the investigator refers to variables that alter the questionnaire's understanding of the research (Low, 2017). This study's reliability test would be measured by applying the alpha of the Cronbach (Cronbach, L.J 1951). The alpha of Cronbach is used to calculate the study's inner consistency. It comprises of an alpha coefficient ranging from 0 to 1 . Values of 0.7 or above show that the same thing is measured by the issue coupled in the scale (Saunders, Lewis and Thornhill, 2012).

Descriptive Analysis

According to Kumar et al. (2013), a descriptive analysis is employed to explain a large amount of data collected through organizing and summarizing the statistics. for this research, the descriptive analysis was conducted to give insights relating to the demographic data. Also, the collected demographic data of the respondents is presented in a form of frequency distribution table.

Validity

A validity test measures the extent of the validity or invalidity of a tool. It shows the connection between an independent variable scale and measure. The information should be both reliable and valid in order to be precise in a study. Measure the validity of the factors in a research is frequently used to measure validity.

\subsubsection{Pearson Correlation Analysis}

Saunders et al. (2009) stated that Pearson Correlation Analysis is enabled to quantify the strength of the linear relationship between two numerical or ranked variables. In this study, Pearson Correlation coefficient is used to analyse the relationship between each variable. The coefficient can take on any value between -1 and +1 ; the value of +1 represents a perfect positive correlation by contrast a value of -1 represents a perfect negative correlation (Saunders et al., 2009). The rules about the Pearson Correlation Analysis are shown in Figure 3.0: 
Figure 3.0: Values of the Pearson Correlation Coefficient

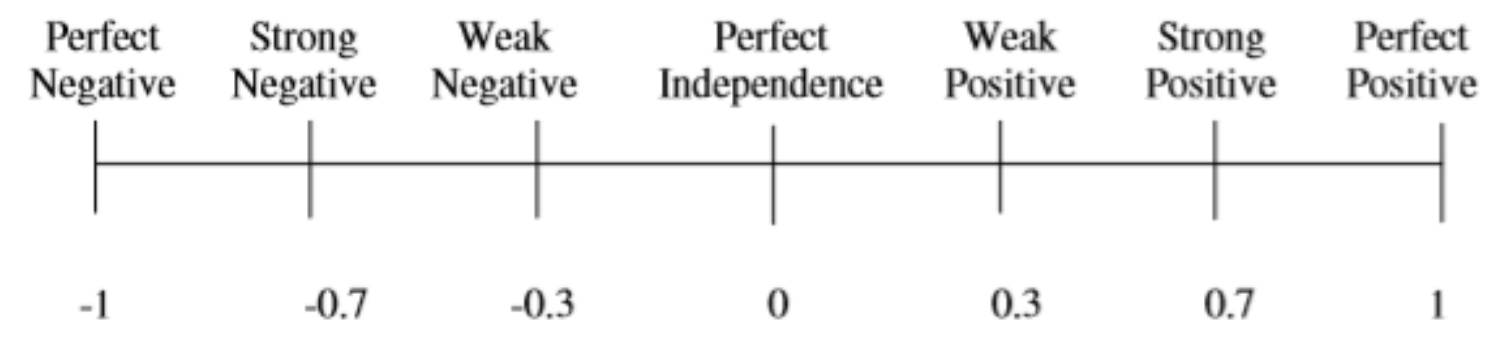

Note. From Saunders, M., Lewis, P., \& Thornhill, A. (2009). Research methods for business students ( $5^{\text {th }}$ ed.). Prentice Hall: Financial Times.

Multiple Regression Analysis

Multiple regression is described as the calculating coefficient of multiple determination and regression equation using two or more independent variables or a measure of linear association that investigates a straight-line relationship (Saunders et al., 2009; Zikmund, 2003). The relationship between independent variables and dependent variable can be determined using a linear equation. According to Saunders et al. (2009) and Zikmund (2003), the multiple regression equation is:

$\mathrm{Y}=\mathrm{a}+\mathrm{bX1}+\mathrm{bX2}+\mathrm{bX} 3+\ldots \ldots \ldots .+\mathrm{bnXn}$

Where: $Y=$ Dependent variable

$a=$ Constant value, the value of $Y$ when the line cuts $Y$ axis all $X$ value $=0$

$b=$ The slope, or change in $Y$ for any corresponding change in one unit of $X$ $X=$ Independent variables use to predict $Y$

Moreover, Zikmund (2003) indicated that coefficient of multiple determinations (adjusted R2) shows the percentage of variation in $Y$ (dependent variable) explained by variation of independent variables. Therefore, this research study will investigate the relationship between independent variables (e-satisfaction, brand involvement and technology) towards moderator (location) and dependent variable (purchase intention). Through the analysis results, researcher is able to have a better understanding of factors affecting online purchase intention of generation $\mathrm{y}$.

\section{Linear Regression Analysis}

Linear regression analysis is used in a situation where one independent variable is hypothesized to affect one dependent variable (Sekaran \& Bougie, 2010). Therefore, linear regression is used to determine the relationship between moderator (location) and dependent variable (purchase intention) in this study. An equation is formed as:

$Y=a+b X$

Where: $Y=$ Dependent variable

$\mathrm{a}=$ Constant value

$b=$ Beta Coefficient Value

$X=$ Variable use to predict $Y$ 


\section{Data Analysis}

Introduction

Chapter 4 will discuss the results and findings obtained through the self-administrated questionnaire. SPSS Version 23 is used to analyze and summarize the collected data.

Data analysis results of this study are presented in this chapter. Data collected from target respondents were analyzed by using Statistical Package for Society Science (SPSS) Version 23. The target respondents are in Klang valley generation y who experienced online shopping. Descriptive analysis, scale measurement, Pearson Correlation, multiple regressions, and linear regressions will be presented.

\section{Response Rate}

A total of 700 questionnaires were administered in Klang valley, out of which 600 were returned resulting in an $85 \%$ percent response rate which was considered adequate. Following the data editing process, 403 questionnaires were found usable. The final sample size adopted in this study was therefore 400 respondents. 18 to 36 years old who were experienced online shopping. This meant that the sample set satisfied the criterion validity requirements.

Demographic Profile

Table 4.0 Summary of respondents' demographic profile

The data analysis shows the basic demographic of the data collected from 400 respondents and the result of the basic background of online purchase intention of generation $\mathrm{Y}^{\prime} \mathrm{s}$.

$\begin{array}{llll}\text { Demographics } & \text { Categories } & \text { Frequency } & \text { Percent \% } \\ \text { Q1. Gender } & \text { Male } & 181 & 44.9 \\ & \text { Female } & 222 & 55.1\end{array}$

According to table of gender, the number of female respondents is more than male respondents. There were $222(55.1 \%)$ female and 181 (44.9\%) male respondents total of 403 respondents.

$\begin{array}{llll}\text { Q2. Age } & 18 \text { to } 23 \text { years old } & 173 & 42.9 \\ 24 \text { to } 29 \text { years old } & 160 & 39.7 \\ 30 \text { to } 36 \text { years old } & 70 & 17.4\end{array}$

Table of age shows that the majority of the respondents are the age group between 18-23 years old (42.9\%), following group of $24-29$ years old (39.7\%) years old and lastly, there are (17.4\%) of the respondents under the age group of 30-36 years old.

$\begin{array}{llll}\text { Q3. Profession } & \text { Student } & 200 & 49.6 \\ & \text { Working adult } & 190 & 47.1 \\ & \text { Unemployed } & 13 & 3.2\end{array}$

Based on profession table, $49.6 \%$ of them were students, followed by $47.1 \%$ of working adult and $3.2 \%$ were unemployed.

Q4. Monthly income Less than RM1000 118

RM1000-RM1999 109




$\begin{array}{lll}\text { RM2000-RM2999 } & 101 & 25.1 \\ \text { RM3000 and above } & 75 & 18.6\end{array}$

According to table of monthly income, $29.3 \%$ respondents earn less than RM1000, followed by $27 \%$ of lower middle income (RM1000-RM1999), $25.1 \%$ with middle income (RM20002999), and lastly $18.6 \%$ with higher income (RM3000 and above).

$\begin{array}{llll}\text { Q5. Ethnicity } & \text { Malay } & 85 & 21.1 \\ & \text { Chinese } & 175 & 43.4 \\ & \text { Indian } & 65 & 16.1 \\ & \text { Others } & 78 & 19.4\end{array}$

Based on table of ethnicity, there are $21.1 \%$ respondents are Malay, followed by Chinese nationality $43.3 \%$. There are $16.1 \%$ of the respondents Indian and lastly $19.4 \%$ with others.

$\begin{array}{llll}\begin{array}{l}\text { Q6. Do you have any } \\ \text { experience Yes (Please proceed }\end{array} \text { of } & \text { to next section) } & 99 \\ \text { shopping for online? } & \begin{array}{l}\text { No (Survey ends } \\ \text { here, Thank you) }\end{array} & 1\end{array}$

Question on general information about experience of online shopping. It is found that $99 \%$ of the respondents have the experience of purchasing products for online shops. However, $1 \%$ of them do not have the experience of online shopping. So, only those respondents who have experience of shopping online would be taken into account for statistical computation.

Preliminary data screening

All data have been screened through and have no missing data identified in the data set. All the outliners have been removed. This is shown in the appendix. All item questions have had outliers cleared out.

Data Analysis

Reliability Test

In reliability analysis, Cronbach's Alpha was used to examine the internal reliability of all 31 items used for this study.

$\begin{array}{lll}\text { Scales } & \text { Number of items } & \text { Cronbach's Alpha } \\ \text { E-satisfaction } & 6 & 0.879 \\ \text { Brand involvement } & 5 & 0.864 \\ \text { Technology } & 6 & 0.881 \\ \text { Purchase intention } & 7 & 0.917 \\ \text { Location } & 7 & 0.909 \\ \text { Total (All Variables) } & 31 & 0.972\end{array}$

Table 4.1: Cronbach's Alpha of Reliability Analysis

Table 4.1 shows that all 31 items were all reliable and valid to measure the opinions of Generation Y's purchase intention on online shopping of products as all values are above 0.7. Based on table, the dependent variables which is Generation Y's Purchase intention on online shopping of products has the highest internal consistency reliability with the alpha values of 0.917. For the moment, moderating reliability Location has the second highest reliability with 
alpha values of 0.909 followed by Technology at 0.881 , E-satisfaction with 0.879 and Brand Involvement with the lowest reliability with values of 0.864 . In conclusion, total variables show alpha value of 0.972 proving that all variables are reliable.

\title{
Exploratory Factor Analysis
}

Factor analysis is a statistical technique used to validate modern tests of the personality to trace its roots to the work of the researchers (Frick, Barry and Kamphaus 2009). The test is used to reduce a large number of variables into fewer numbers of factors to extract minimum common variance from all variables and puts them in a common score. Using the Kolmogorov method, the graphical analysis was followed by the numerical normality analysis. The results of the Kolmogorov Test resulted in the normal distribution of the data collection.

Exploratory factor analysis is tested using factor loading method in numerical form. The range of factor loadings are from negative one $(-1)$ to positive one $(+1)$ to show the correlation of the questions to the dependent or independent variables.

\author{
Kaiser-Meyer-Olkin (KMO) \\ 0.00 to 0.49 unacceptable \\ 0.50 to 0.59 miserable \\ 0.60 to 0.69 mediocre \\ 0.70 to 0.79 middling \\ 0.80 to 0.89 meritorious \\ 0.90 to 1.00 marvelous \\ Table 4.2: Results of KMO
}

(Source: Kaiser 1974) 
INTERNATIONAL JOURNAL OF ACADEMIC RESEARCH IN BUSINESS AND SOCIAL SCIENCES Vol. 11, No. 4, 2021, E-ISSN: 2222-6990 ㄷ 2021 HRMARS

Normality test

Table 4.13: Descriptive Statistics

\begin{tabular}{|c|c|c|c|c|c|c|c|}
\hline $\begin{array}{c}\text { Minim } \\
\text { um }\end{array}$ & $\begin{array}{l}\text { Maxim } \\
\text { um }\end{array}$ & Mean & $\begin{array}{c}\text { Std. } \\
\text { Deviatio } \\
\mathrm{n}\end{array}$ & Ske & less & Kur & \\
\hline $\begin{array}{c}\text { Statisti } \\
\text { C }\end{array}$ & $\begin{array}{c}\text { Statisti } \\
\text { C }\end{array}$ & Statistic & Statistic & $\begin{array}{c}\text { Statisti } \\
\text { C }\end{array}$ & $\begin{array}{l}\text { Std. } \\
\text { Error }\end{array}$ & Statistic & $\begin{array}{l}\text { Std. } \\
\text { Error }\end{array}$ \\
\hline
\end{tabular}

\begin{tabular}{|c|c|c|c|c|c|c|c|c|c|}
\hline esat1 & 400 & 3 & 5 & 4.44 & .669 & -.789 & .122 & -.499 & .243 \\
\hline esat2 & 400 & 3 & 5 & 4.42 & .659 & -.705 & .122 & -.563 & .243 \\
\hline esat3 & 400 & 3 & 5 & 4.43 & .660 & -.737 & .122 & -.532 & .243 \\
\hline esat4 & 400 & 3 & 5 & 4.43 & .645 & -.678 & .122 & -.549 & .243 \\
\hline esat5 & 400 & 3 & 5 & 4.46 & .652 & -.816 & .122 & -.411 & .243 \\
\hline esat6 & 400 & 3 & 5 & 4.44 & .662 & -.779 & .122 & -.488 & .243 \\
\hline $\begin{array}{l}\text { brandin } \\
1\end{array}$ & 400 & 3 & 5 & 4.46 & .692 & -.894 & .122 & -.444 & .243 \\
\hline $\begin{array}{l}\text { brandin } \\
2\end{array}$ & 400 & 3 & 5 & 4.36 & .672 & -.582 & .122 & -.712 & .243 \\
\hline $\begin{array}{l}\text { brandin } \\
3\end{array}$ & 400 & 3 & 5 & 4.45 & .662 & -.795 & .122 & -.469 & .243 \\
\hline $\begin{array}{l}\text { brandin } \\
4\end{array}$ & 400 & 3 & 5 & 4.45 & .651 & -.765 & .122 & -.472 & .243 \\
\hline $\begin{array}{l}\text { brandin } \\
5\end{array}$ & 400 & 3 & 5 & 4.46 & .682 & -.889 & .122 & -.412 & .243 \\
\hline tech1 & 400 & 3 & 5 & 4.49 & .653 & -.896 & .122 & -.303 & .243 \\
\hline tech2 & 400 & 3 & 5 & 4.43 & .649 & -.706 & .122 & -.532 & .243 \\
\hline tech3 & 400 & 3 & 5 & 4.43 & .657 & -.735 & .122 & -.523 & .243 \\
\hline tech4 & 400 & 3 & 5 & 4.44 & .669 & -.797 & .122 & -.490 & .243 \\
\hline tech5 & 400 & 3 & 5 & 4.41 & .655 & -.678 & .122 & -.576 & .243 \\
\hline tech6 & 400 & 3 & 5 & 4.43 & .645 & -.686 & .122 & -.542 & .243 \\
\hline purin1 & 400 & 3 & 5 & 4.45 & .677 & -.848 & .122 & -.454 & .243 \\
\hline purin2 & 400 & 3 & 5 & 4.43 & .664 & -.747 & .122 & -.533 & .243 \\
\hline purin3 & 400 & 3 & 5 & 4.42 & .689 & -.772 & .122 & -.589 & .243 \\
\hline purin4 & 400 & 3 & 5 & 4.37 & .667 & -.594 & .122 & -.685 & .243 \\
\hline purin5 & 400 & 3 & 5 & 4.42 & .667 & -.724 & .122 & -.567 & .243 \\
\hline purin6 & 400 & 3 & 5 & 4.43 & .649 & -.697 & .122 & -.540 & .243 \\
\hline purin7 & 400 & 3 & 5 & 4.44 & .661 & -.762 & .122 & -.506 & .243 \\
\hline loc1 & 400 & 3 & 5 & 4.50 & .605 & -.805 & .122 & -.336 & .243 \\
\hline loc2 & 400 & 3 & 5 & 4.47 & .625 & -.755 & .122 & -.424 & .243 \\
\hline loc3 & 400 & 3 & 5 & 4.46 & .663 & -.838 & .122 & -.417 & .243 \\
\hline loc4 & 400 & 3 & 5 & 4.44 & .657 & -.752 & .122 & -.506 & .243 \\
\hline loc5 & 400 & 3 & 5 & 4.41 & .676 & -.702 & .122 & -.620 & .243 \\
\hline loc6 & 400 & 3 & 5 & 4.48 & .656 & -.871 & .122 & -.351 & .243 \\
\hline loc7 & 400 & 3 & 5 & 4.42 & .685 & -.765 & .122 & -.585 & .243 \\
\hline
\end{tabular}


Based on the data collected from 403 respondents' valid respondents 400 , a normality test is done to ensure that there is data collected are normally distributed. The data with the highest skewness is -0.582 while the lowest skewness is -0.894 . On the other hand, Kurtosis shows that the highest is -0.303 and the lowest is -0.712 . According to Hair at al. (1998), normality is used to define the degree to which the distribution of the sample data corresponds to a normal distribution. The kurtosis and skewness of the data collected were analyzed and displayed on table 4.13. The skewness values for all the 31 items used in the questionnaire were within the range of $-1+1$ and the kurtosis value for the all items are within the range of $-1+1$. According to Hair et al (2010), a set of data is normally distributed if the skewness value is between the range's pf -1 and +1 and the kurtosis value are between -+1.96 which responds to a 0.05 degree of error.

Normality test of Purchase Intention of GEN Y (PI)

\section{Descriptives}

\begin{tabular}{|c|c|c|c|c|}
\hline \multirow{14}{*}{ purchint } & & & Statistic & Std. Error \\
\hline & \multirow{3}{*}{$\begin{array}{l}\text { Mean } \\
95 \% \text { Confidence } \\
\text { Interval for Mean }\end{array}$} & & 4.4229 & .02728 \\
\hline & & Lower Bound & 4.3692 & \\
\hline & & $\begin{array}{l}\text { Upper } \\
\text { Bound }\end{array}$ & 4.4765 & \\
\hline & 5\% Trimmed Mean & & 4.4623 & \\
\hline & Median & & 4.5714 & \\
\hline & Variance & & .298 & \\
\hline & Std. Deviation & & .54557 & \\
\hline & Minimum & & 3.00 & \\
\hline & Maximum & & 5.00 & \\
\hline & Range & & 2.00 & \\
\hline & Interquartile Range & & 1.00 & \\
\hline & Skewness & & -.677 & .122 \\
\hline & Kurtosis & & -.356 & .243 \\
\hline
\end{tabular}

Table 4.14: Descriptive statistics for PI (Source: Research's own analysis)

Table 4.14 has shown the mean value $=4.4229$, Skewness $=-0.677$ and Kurtosis $=-0.356$. Mean is the measurement of an average point of $\mathrm{PI}$. In this analysis, results are showing the responses were all given 4 and above as all the variables is using a Likert 5-point scale to in the research survey questionnaire. 


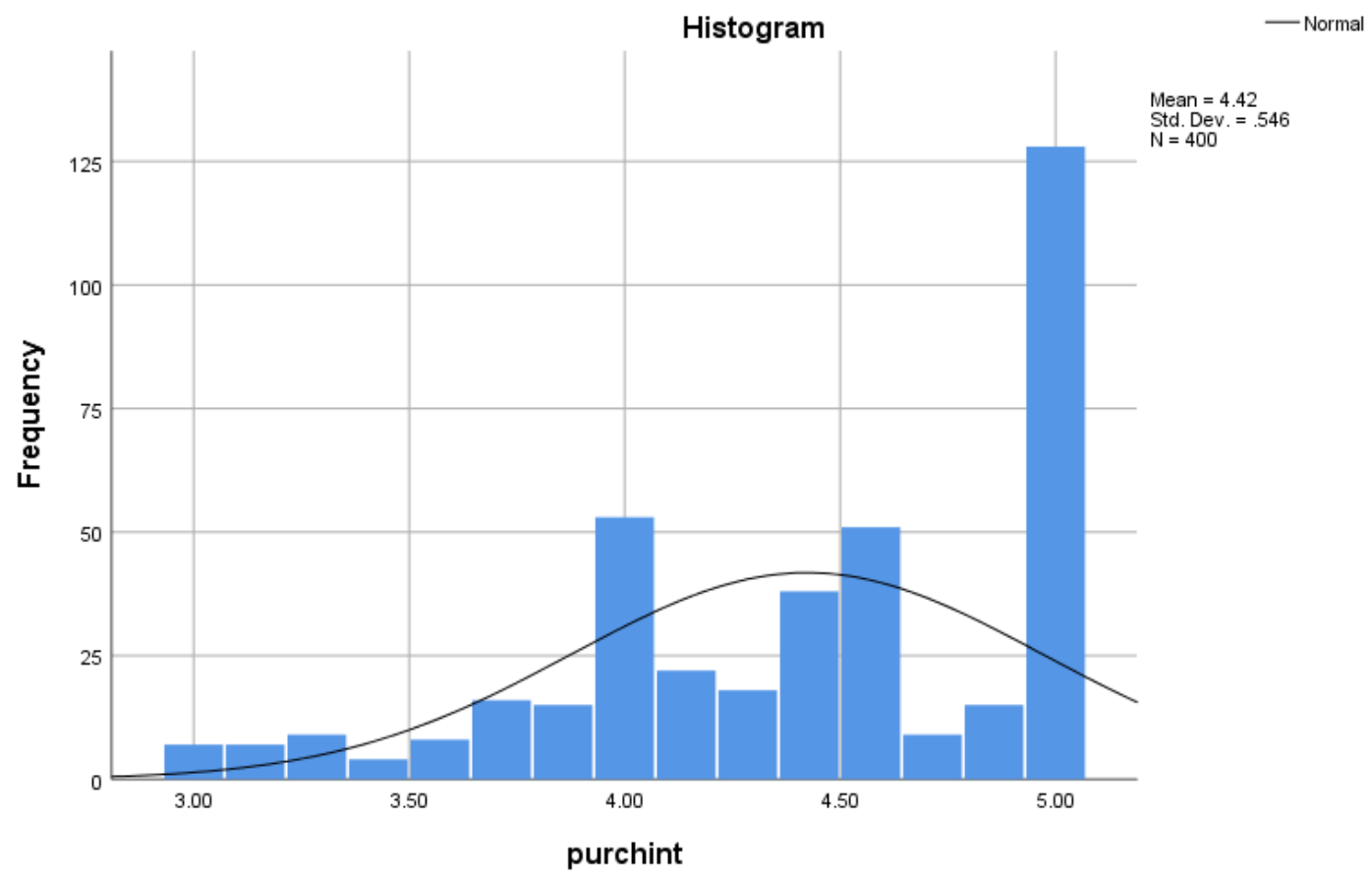

Figure 4.0: Histogram for PI (Source: Researcher's own analysis)

Figure 4.0 is histogram which showed the skewness and kurtosis of PI. Skewness sows that whether the data is skewed to the right or left. In this study, independent variable PI had the skewness of -0.677 which shows that the data is negatively skewed distribution, they were skewed to the left, which means that the left tail was longer. The result showed that the distribution was highly skewed as it is fall under -1 or greater than +1 .

Kurtosis is measuring the whether the tail of the data is light-tailed, heavy tailed or normally distributed. In this study, it was shown that the kurtosis of PI as an independent variable was -0.356. This indicated that PI has a platykurtic distribution where it has lighter tail and flatter peak, because the extreme values are less than that of the normal distribution. 


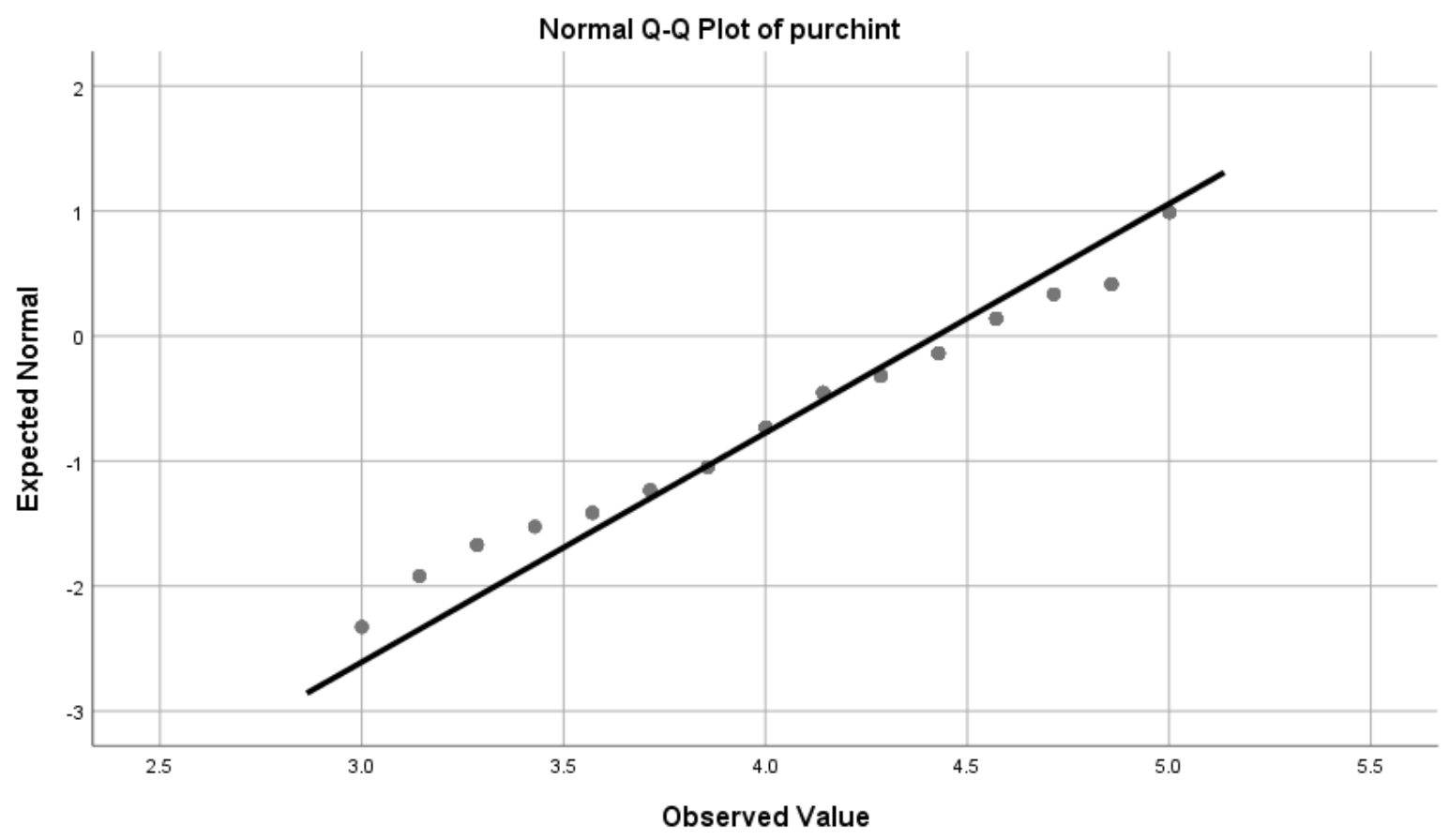

Figure 4.1 Normal QQ plot of PI (Source: Researchers own analysis)

Figure 4.1 showed that the data is assumed normally distributed.

Normality test of E-Satisfaction (ESAT)

\section{Descriptives}

\begin{tabular}{lll|r|r}
\hline esatsmean & & Statistic & Std. Error \\
\cline { 2 - 5 } $\begin{array}{l}\text { Mean } \\
\text { Interval for Mean }\end{array}$ & 4.4367 & .02596 \\
\cline { 2 - 5 } & $\begin{array}{c}\text { Lower Bound } \\
\text { Upper }\end{array}$ & 4.3856 & \\
\hline Bound & 4.4877 & \\
\hline Medrimmed Mean & & & \\
\hline Variance & 4.4722 & \\
\hline Std. Deviation & 4.5000 & \\
\hline Minimum & .270 & \\
\hline Maximum & .51921 & \\
\hline Range & 3.00 & \\
\hline Interquartile Range & 5.00 & \\
\hline Skewness & 2.00 & \\
\hline Kurtosis & 1.00 & \\
\hline
\end{tabular}

Table 4.15: Descriptive statistics for ESAT (Source: Research's own analysis)

Table 4.15 has shown the mean value $=4.4367$, Skewness $=-0.591$ and Kurtosis $=-0.415$. Mean is the sum of all measurements divided by the number of measurements as to obtain the average of the measurement. In this analysis, it shows that the independent variables of ESAT 
has supported the PI as the results are showing the responses were all given 4 and above as the researcher is using a Likert 5 - point scale to test all the variables.

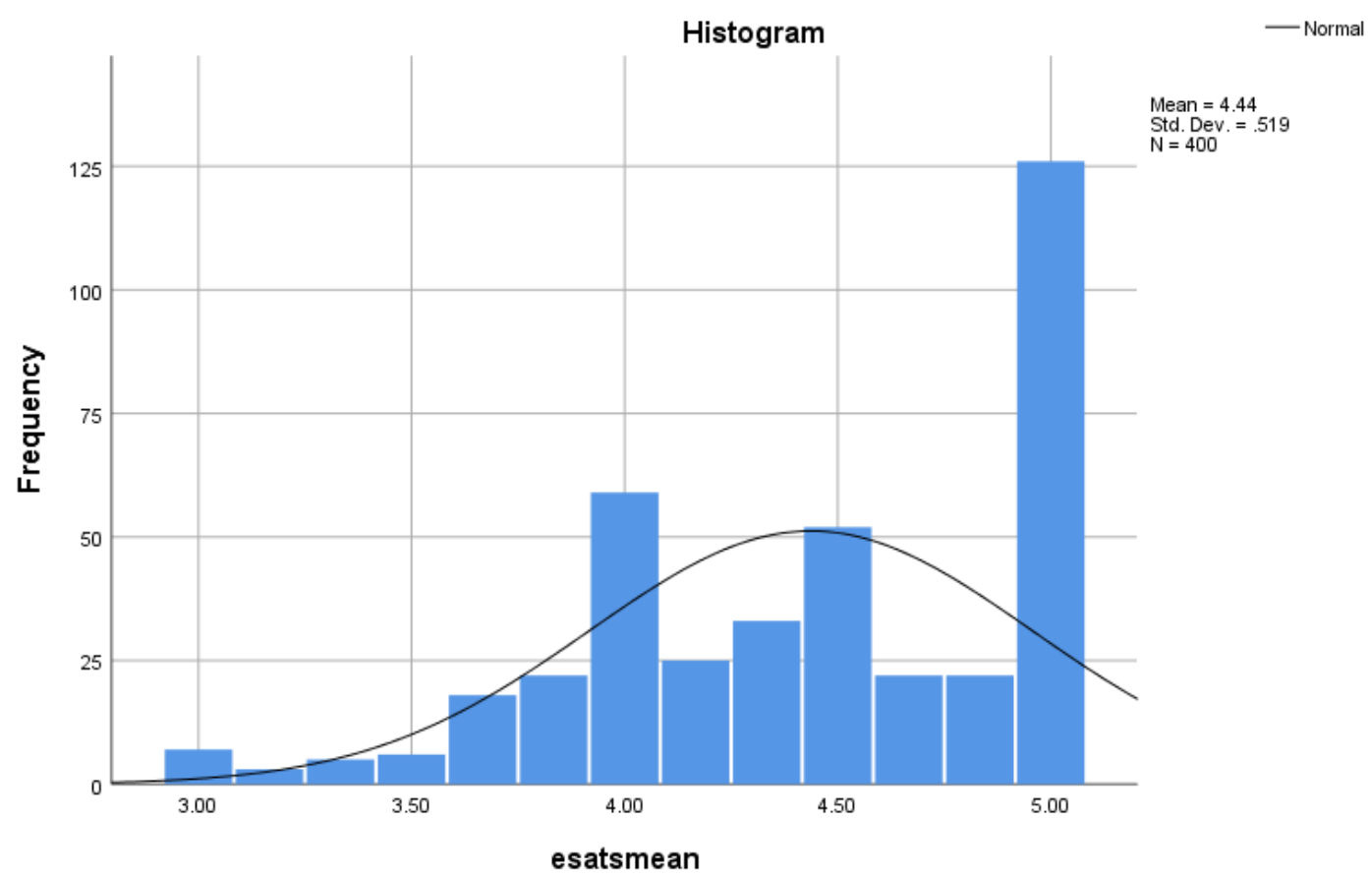

Figure 4.2: Histogram for ESAT (Source: Researcher's own analysis)

Figure 4.2 is histogram which showed the skewness and kurtosis of ESAT. Skewness shows that whether the data is skewed to the right or left. Negative value indicate that it is left skew whereas positive value indicate that it is right skew. In this study, the independent variable ESAT had the skewness of -0.591 . This indicated that the data were negatively skewed or in other words, they were skewed to the left, which means that the left tail was longer. The result showed that the distribution was highly skewed as it is fall under -1 or greater than +1 . Kurtosis is measuring the whether the tail of the data is light tailed, heavy tailed or normally distributed. In this study, it shows that the kurtosis for independent variable was -0.415 . This indicated that $\mathrm{PI}$ has a platykurtic distribution where it has lighter tail and flatter peak, because the extreme values are less than that of the normal distribution.

Hence, ESAT as the independent variable of $\mathrm{PI}$ is valid and acceptable. 


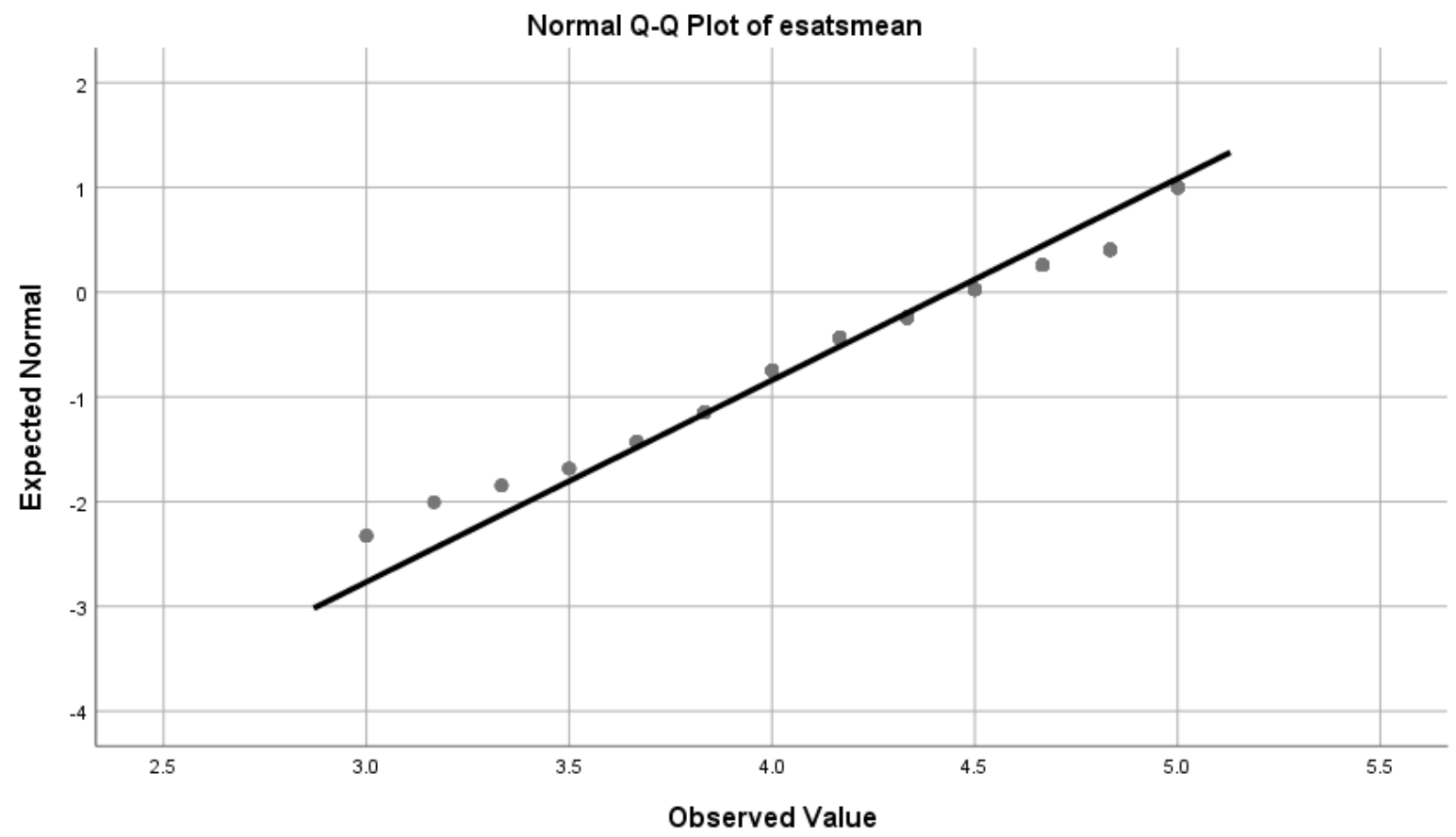

Figure 4.3 Normal QQ plot of ESAT (Source: Researchers own analysis)

Figure 4.3 shows the data is assumed normally distributed.

Normality test of Brand Involvement (BI)

\begin{tabular}{|c|c|c|c|c|}
\hline \multicolumn{5}{|c|}{ Descriptives } \\
\hline & & & Statistic & Std. Error \\
\hline \multirow{13}{*}{$\begin{array}{l}\text { brandinten } \\
\mathrm{t}\end{array}$} & Mean & & 4.4355 & .02705 \\
\hline & 95\% Confidence & Lower Bound & 4.3823 & \\
\hline & Interval for Mean & $\begin{array}{l}\text { Upper } \\
\text { Bound }\end{array}$ & 4.4887 & \\
\hline & $5 \%$ Trimmed Mean & & 4.4750 & \\
\hline & Median & & 4.6000 & \\
\hline & Variance & & .293 & \\
\hline & Std. Deviation & & .54108 & \\
\hline & Minimum & & 3.00 & \\
\hline & Maximum & & 5.00 & \\
\hline & Range & & 2.00 & \\
\hline & Interquartile Range & & 1.00 & \\
\hline & Skewness & & -.710 & .122 \\
\hline & Kurtosis & & -.326 & .243 \\
\hline
\end{tabular}

Table 4.16: Descriptive statistics for BI (Source: Research's own analysis)

As it is shown in the table 4.16, Bl's mean value $=4.4355$, Skewness $=-0.710$ and Kurtosis $=-$ 0.326. Mean is the average that is used to find the central tendency in a set of data. In this case, it shows that the independent variable of $\mathrm{BI}$ is supporting the $\mathrm{PI}$ as the result are showing 
the responses were all above 4 and above as the research survey questionnaire used Likert 5point scale to examine the variable.

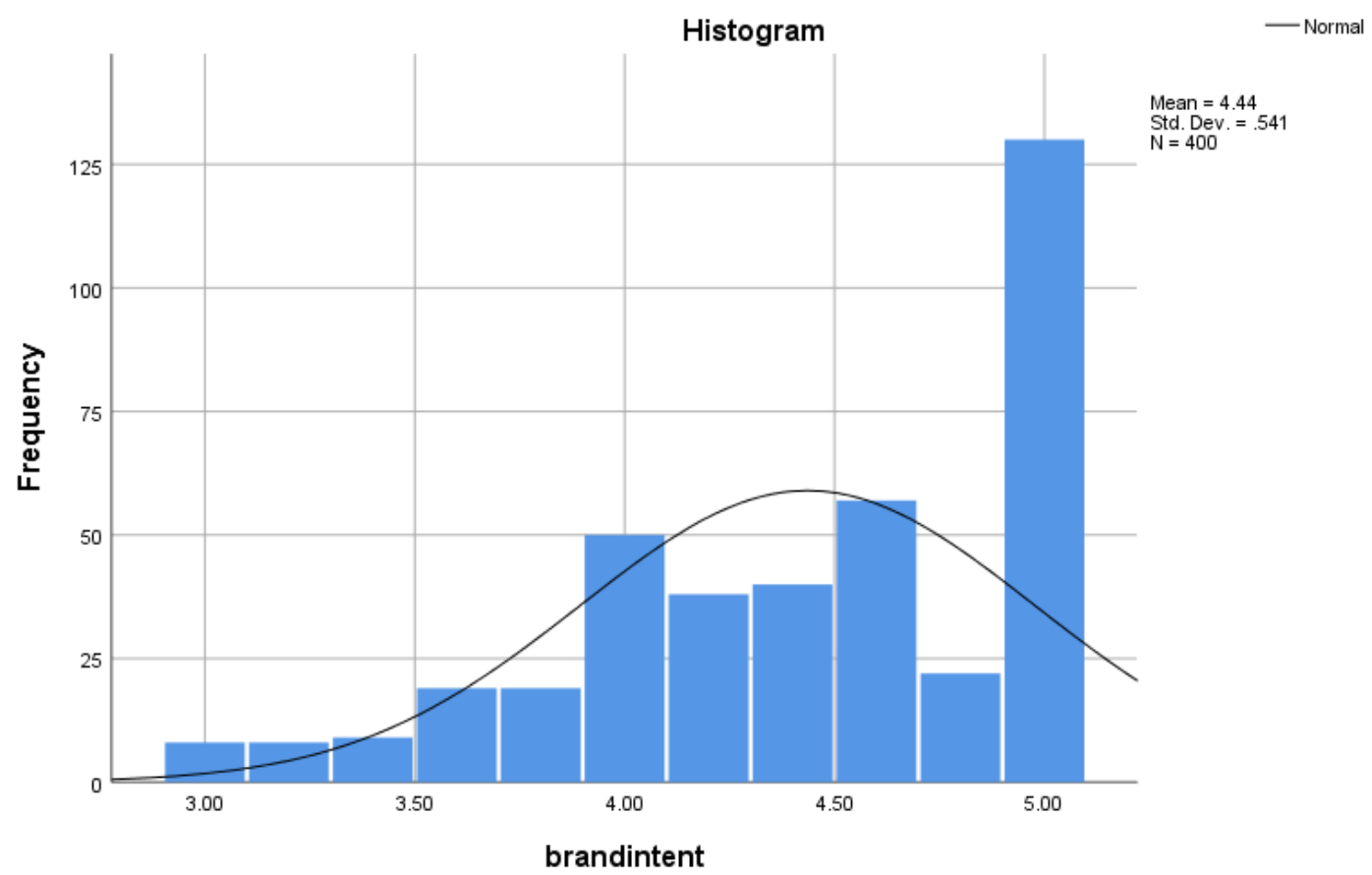

Figure 4.4: Histogram for BI (Source: Researcher's own analysis)

Figure 4.4 is histogram which produced to showed the skewness and kurtosis of BI. In PI study, the independent variable BI had the skewness of -0.710 . This indicated that the data were negatively skewed or in other words, they were skewed to the left, which means that the left tail was longer. The result showed that the distribution was highly skewed as it is fall under 1 or greater than +1 .

Kurtosis measure the thickness of the tails of a distribution. In this study, it was shown that the kurtosis of $\mathrm{BI}$ as an independent variable was -0.326 . this indicated that $\mathrm{BI}$ has a mesokurtic distribution where it has a long tail and it is skinny.

Mesokurtic distribution has kurtosis statistic similar to that of the normal distribution. It means that the extreme values of the distribution are similar to that of a normal distribution characteristic. This definition is used so that the standard normal distribution has a kurtosis of three.

Therefore, $\mathrm{BI}$ as the independent variable of $\mathrm{PI}$ is valid and acceptable 


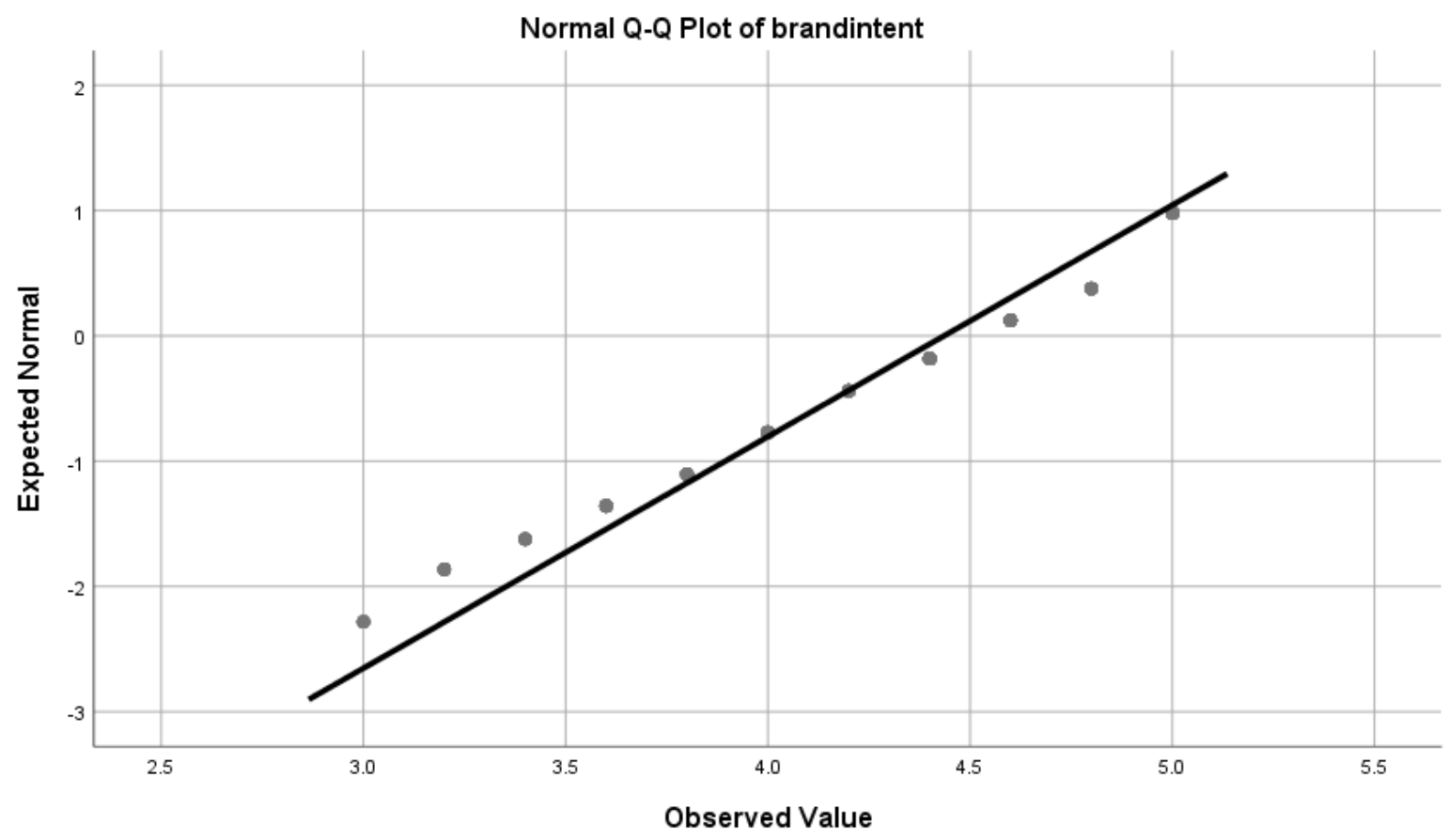

Figure 4.5 Normal QQ plot of BI (Source: Researchers own analysis)

Figure 4.5 showed that the data is assumed normally distributed.

Normality test of Technology

\section{Descriptives}

Statistic Std. Error

\begin{tabular}{ll|r|r|}
\hline techno & & 4.4372 & .02597 \\
\cline { 2 - 4 } $\begin{array}{l}\text { Mean } \\
\text { Interval for Mean }\end{array}$ & $\begin{array}{l}\text { Lower Bound } \\
\text { Upper }\end{array}$ & 4.3861 & \\
\hline B\% Trimmed Mean & 4.4882 & \\
\hline Median & 4.4735 & \\
\hline Variance & 4.5000 & \\
\hline Std. Deviation & .270 & \\
\hline Minimum & .51949 & \\
\hline Maximum & 3.00 & \\
\hline Range & 5.00 & \\
\hline Interquartile Range & 2.00 & \\
\hline Skewness & 1.00 & \\
\hline Kurtosis & -.640 & .122 \\
\hline
\end{tabular}

Table 4.17: Descriptive statistics for Technology (Source: Research's own analysis)

Table 4.17 has shown the mean value $=4.4372$, Skewnes -0.640 and Kurtosis $=-0.299$. Mean is the measurement of an average point of technology. In this analysis, it shows that the 
independent variables of technology are supporting the PI as the results are showing the responses were all given 4 and above as the variables is using a Likert 5-point scale to in the research survey questionnaire.

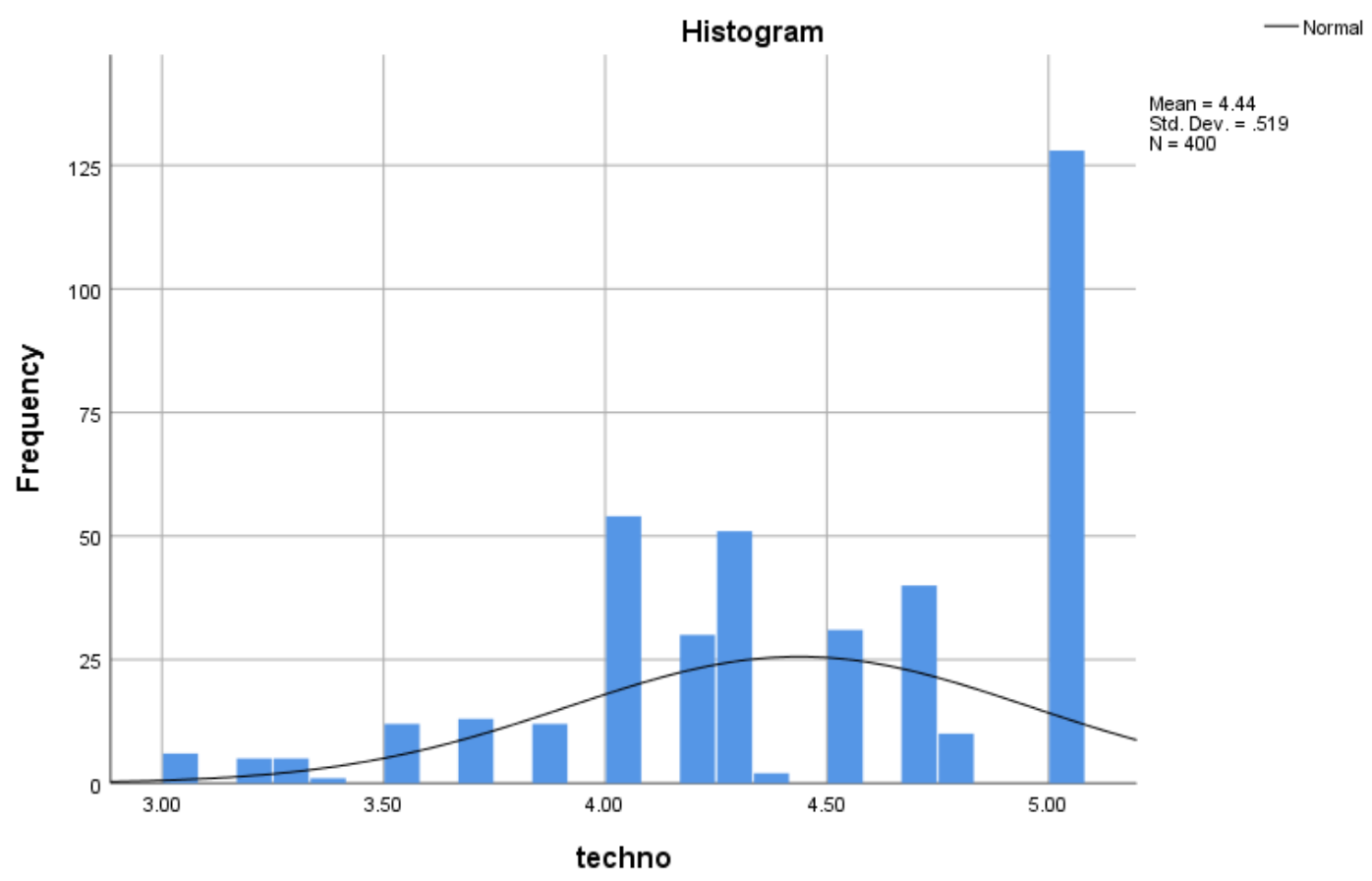

Figure 4.6: Histogram for Technology (Source: Researcher's own analysis)

Figure 4.6 is histogram which showed the skewness and kurtosis of Technology. Skewness shows that whether the data is skewed to the right or left. In this study, the independent variable technology had the skewness of -0.640 which shows that the data is negatively skewed distribution, they were skewed to the left, which means that the left tail was longer. The result showed that the distribution was highly skewed as it is fall under -1 or greater than +1 .

Kurtosis measure the thickness of the tails of a distribution. In this study, it was shown that the kurtosis of technology as an independent variable was -0.299 . This indicated that technology has a platykurtic distribution where it has lighter tail and flatter peak, because the extreme values are less than that of the normal distribution.

Thus, technology as the independent variable of PI is valid and acceptable. 


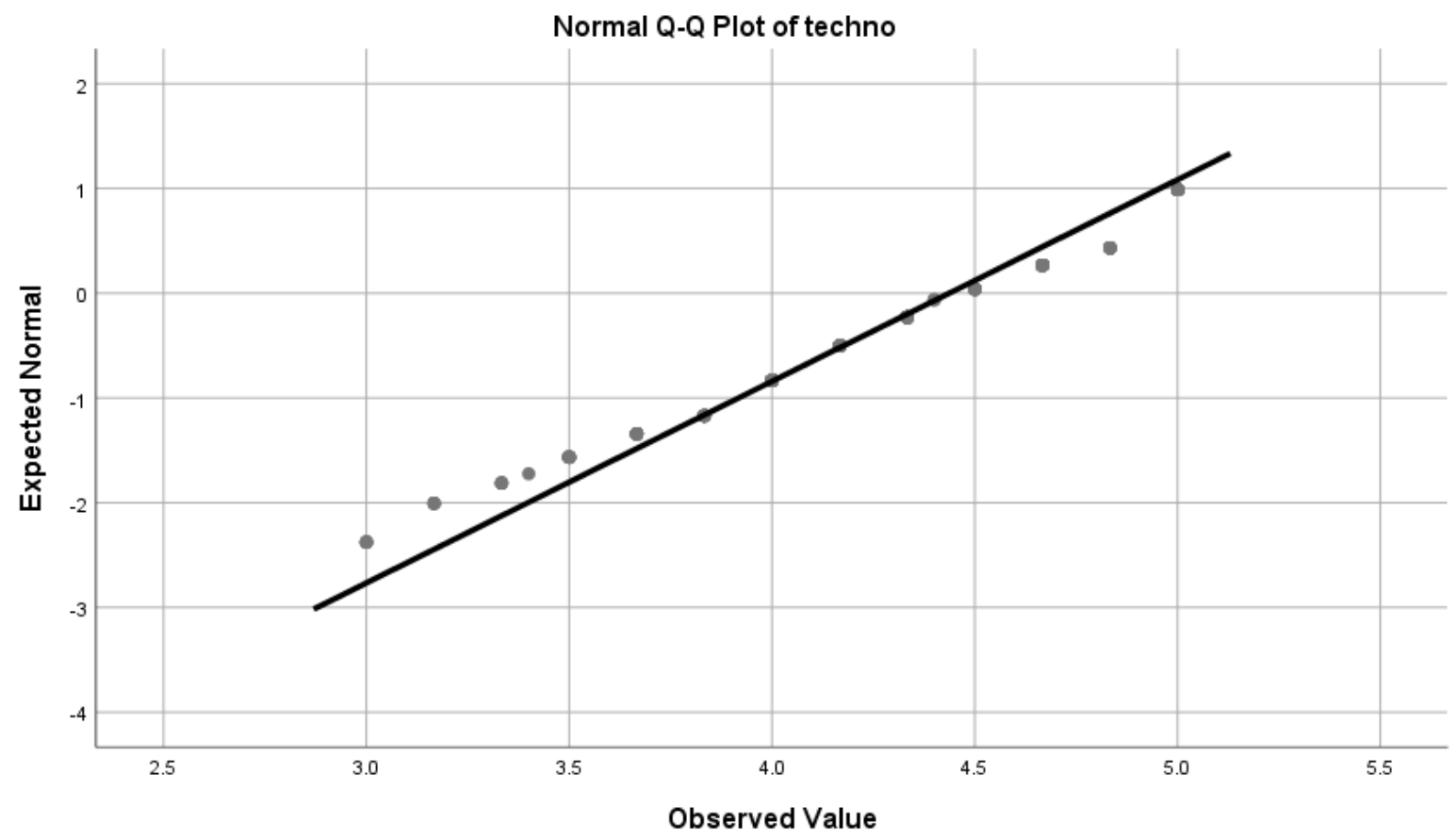

Figure 4.7 Normal QQ plot of Technology (Source: Researchers own analysis)

Figure 4.7 showed that the data is assumed normally distributed.

Normality test of Location

\section{Descriptives}

\begin{tabular}{llr|r}
\hline & Statistic & Std. Error \\
\hline locat & & 4.4532 & .02625 \\
\cline { 2 - 5 } $\begin{array}{l}\text { Mean } \\
\text { Interval for Mean }\end{array}$ & $\begin{array}{l}\text { Lower Bound } \\
\text { Upper }\end{array}$ & 4.4016 & \\
\hline B\% Trimmed Mean & 4.5048 & \\
\hline Median & & \\
\hline Variance & 4.4917 & \\
\hline Std. Deviation & 4.5714 & \\
\hline Minimum & .276 & \\
\hline Maximum & .52492 & \\
\hline Range & 3.00 & \\
\hline Interquartile Range & 5.00 & \\
\hline Skewness & 2.00 & \\
\hline Kurtosis & 1.00 & \\
\hline
\end{tabular}

Table 4.18: Descriptive statistics for Location (Source: Research's own analysis)

As it is shown in the table 4.18, Location's mean value $=4.4532$, Skewness $=-0.680$ and Kurtosis $=-0.272$. Mean is the average that is used to find the central tendency in a set of data. 
In this case, it shows that the moderating variables of Location is moderating $\mathrm{Pl}$ as the results are showing the responses were all given 4 and above as all the variables is using a Likert 5point scale to in the research survey questionnaire.

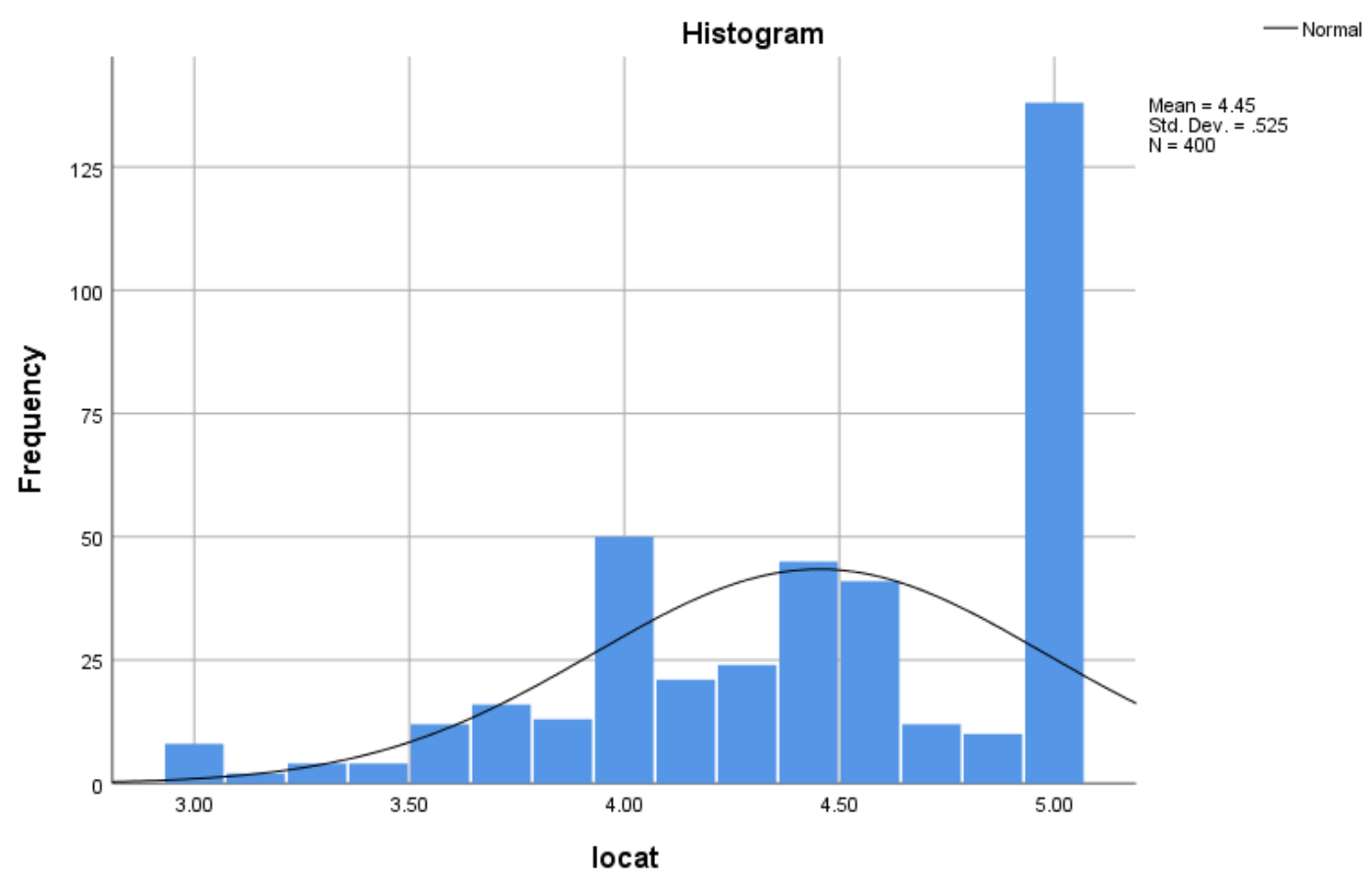

Figure 4.8: Histogram for Location (Source: Researcher's own analysis)

Figure 4.8 is histogram which produced to show the skewness and kurtosis of Location. Skewness indicated that whether the data is skewed to the right or left of the curve. In PI study, the moderating variable Location had the skewness of -0.680 . this indicated that the data were negatively skewed or in other words, they were skewed to the left, which means that the left tail was longer. The result showed that the distribution was highly skewed as it is fall under -1 or greater than +1 .

Kurtosis measure the thickness of the tails of a distribution. In this study, it was shown that the kurtosis of Location as a moderating variable was -0.272 . this shows that this dependent variable has a platykurtic distribution where it has lighter tail and flatter peak, because the extreme values are less than that of the normal distribution.

Therefore, Location as the moderating variable of $\mathrm{PI}$ is valid and acceptable. 


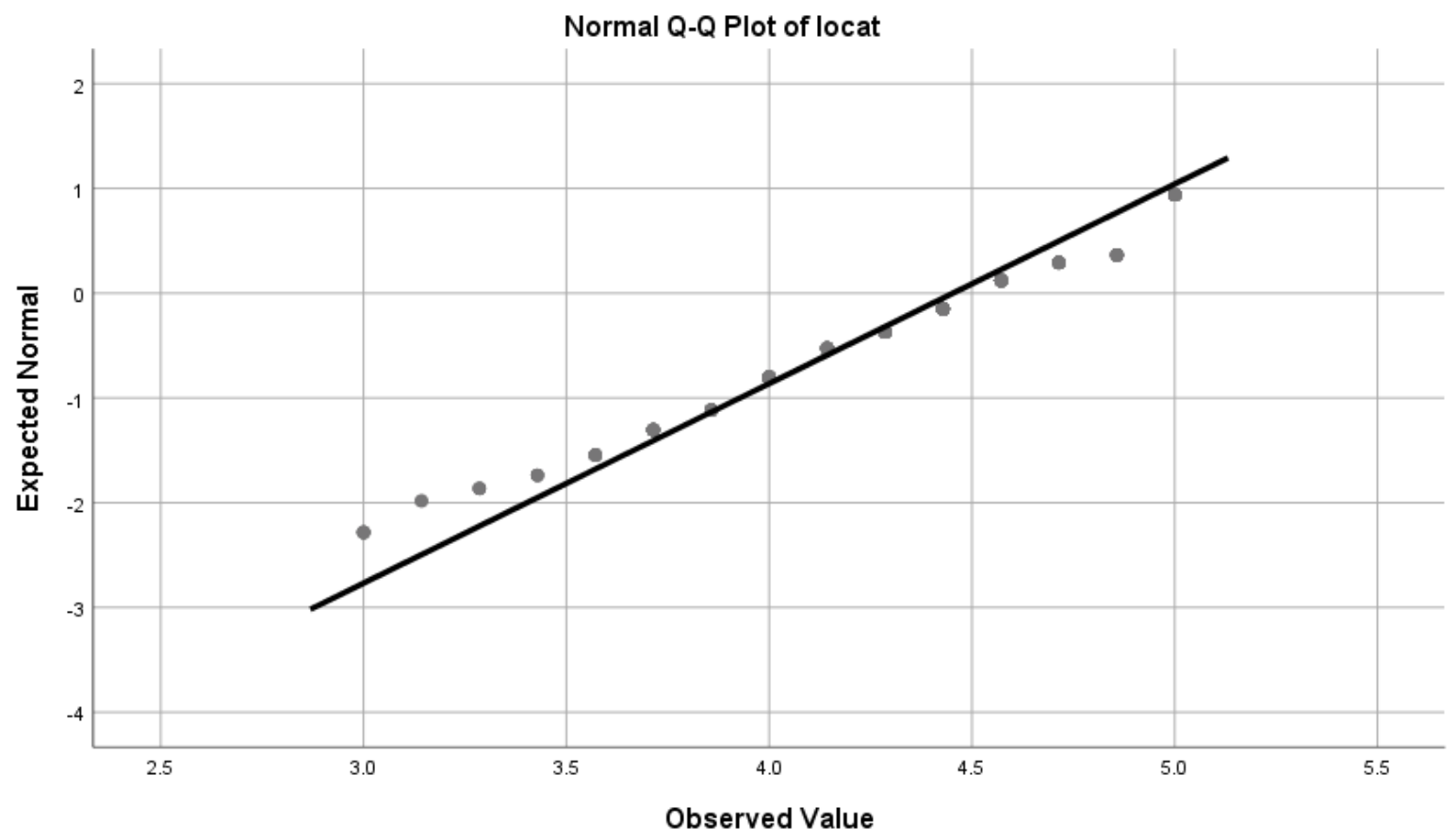

Figure 4.9 Normal QQ plot of Location (Source: Researchers own analysis)

Figure 4.9 showed that the data is assumed normally distributed.

Kolmogorov-Smirnova and Shapiro-Wilk test

Tests of Normality

Kolmogorov-Smirnov ${ }^{\text {a }}$ Shapiro-Wilk

\begin{tabular}{l|r|r|r|r|r|r} 
& Statistic & \multicolumn{1}{c|}{ df } & \multicolumn{1}{c|}{ Sig. } & Statistic & \multicolumn{1}{c|}{ df } & \multicolumn{1}{c}{ Sig. } \\
\hline locat & .196 & 400 & .000 & .884 & 400 & .000 \\
\hline esatsmean & .176 & 400 & .000 & .893 & 400 & .000 \\
\hline $\begin{array}{l}\text { brandinten } \\
\mathrm{t}\end{array}$ & .177 & 400 & .000 & .886 & 400 & .000 \\
\hline techno & .181 & 400 & .000 & .895 & 400 & .000 \\
\hline purchint & .175 & 400 & .000 & .889 & 400 & .000 \\
\hline
\end{tabular}

a. Lilliefors Significance Correction

Table 4.19: Kolmogorov-Smirnova and Shapiro-Wilk test for PI

(Source: researcher's own analysis)

In this analysis, PI has performed Kolmogorov-Smirnova and Shapiro-Wilk test (Table 4.19). Any $p$ value (significant) less than 0.05 mean that the data is not normally distributed. In the Kolmogorov-Smirnova test, the Location, ESAT, BI, Technology and PI has $p$ value which is less than 0.05. thus, the data is a statistically different between the data with the normal distribution.

Shapiro-Wilk test is a powerful test where it can be used to test for small to big sample size. PI study has a sample size of 400 respondents; therefore, the result shall base on these two tests. It shows that all the variables have $P$ value less than 0.05 , thus, the null hypothesis will 
be rejected. There is a statistically significantly different between the data with the normal distribution, so all the variables are not normally distributed.

Validity Test

Validity will show that whether PI research truly calculates what it intends to know and how true is the research outcome of PI. The validity of the collected data from the sample lies on the relevance and appropriateness of the research questions as well as the relations with the concept scrutiny.

\begin{tabular}{|c|c|c|c|c|c|c|}
\hline \multicolumn{7}{|c|}{ Table 4.20 Correlations } \\
\hline & & esatsmean & $\begin{array}{c}\text { brandinten } \\
t\end{array}$ & techno & purchint & locat \\
\hline \multirow[t]{3}{*}{ esatsmean } & $\begin{array}{l}\text { Pearson } \\
\text { Correlation }\end{array}$ & 1 & $.814^{* *}$ & $.814^{* *}$ & $.808^{* *}$ & $.790^{* *}$ \\
\hline & Sig. (2-tailed) & & .000 & .000 & .000 & .000 \\
\hline & $\mathrm{N}$ & 400 & 400 & 400 & 400 & 400 \\
\hline \multirow[t]{3}{*}{$\begin{array}{l}\text { brandinten } \\
t\end{array}$} & $\begin{array}{l}\text { Pearson } \\
\text { Correlation }\end{array}$ & $.814^{* *}$ & 1 & $.821^{* *}$ & $.823^{* *}$ & $.771^{* *}$ \\
\hline & Sig. (2-tailed) & .000 & & .000 & .000 & .000 \\
\hline & $\mathrm{N}$ & 400 & 400 & 400 & 400 & 400 \\
\hline \multirow[t]{3}{*}{ techno } & $\begin{array}{l}\text { Pearson } \\
\text { Correlation }\end{array}$ & $.814^{* *}$ & $.821^{* *}$ & 1 & $.838^{* *}$ & $.842^{* *}$ \\
\hline & Sig. (2-tailed) & .000 & .000 & & .000 & .000 \\
\hline & $\mathrm{N}$ & 400 & 400 & 400 & 400 & 400 \\
\hline \multirow[t]{3}{*}{ purchint } & $\begin{array}{l}\text { Pearson } \\
\text { Correlation }\end{array}$ & $.808^{* *}$ & $.823^{* *}$ & $.838^{* *}$ & 1 & $.817^{* *}$ \\
\hline & Sig. (2-tailed) & .000 & .000 & .000 & & .000 \\
\hline & $\mathrm{N}$ & 400 & 400 & 400 & 400 & 400 \\
\hline \multirow[t]{3}{*}{ locat } & $\begin{array}{l}\text { Pearson } \\
\text { Correlation }\end{array}$ & $.790^{* *}$ & $.771^{* *}$ & $.842^{* *}$ & $.817^{* *}$ & 1 \\
\hline & Sig. (2-tailed) & .000 & .000 & .000 & .000 & \\
\hline & $\mathrm{N}$ & 400 & 400 & 400 & 400 & 400 \\
\hline
\end{tabular}

**. Correlation is significant at the 0.01 level (2-tailed).

(Source: researcher's own analysis)

A Pearson product-moment correlation was run to determine the relationship between each items of relationship (e-satisfaction, brand involvement, technology, purchase intention, location). The data in table 4.20 showed no violation of normality and linearity. There is significant relationship between all 5 of the items of relationship. 


\begin{tabular}{|c|c|c|c|}
\hline \multicolumn{4}{|c|}{ Correlations } \\
\hline & & esatsmean & purchint \\
\hline \multirow[t]{3}{*}{ esatsmean } & $\begin{array}{l}\text { Pearson } \\
\text { Correlation }\end{array}$ & 1 & $.808^{* *}$ \\
\hline & Sig. (2-tailed) & & .000 \\
\hline & $\mathrm{N}$ & 400 & 400 \\
\hline \multirow[t]{3}{*}{ purchint } & $\begin{array}{l}\text { Pearson } \\
\text { Correlation }\end{array}$ & $.808^{* *}$ & 1 \\
\hline & Sig. (2-tailed) & .000 & \\
\hline & $\mathrm{N}$ & 400 & 400 \\
\hline
\end{tabular}

**. Correlation is significant at the 0.01 level (2-tailed).

\subsubsection{Table 4.21: Correlation result of E-Satisfaction} (Source: Researchers own analysis)

Pearson's correlation coefficient was used to measure the strength of the relationship between two variables which are E-satisfaction and online purchase intention of Generation Y. Based on table 4.21 the significance value ( $p$-value) is 0.000 . This indicates that the correlation between e-satisfaction and online purchase intention of Generation $Y$ is significant.

Besides that, the correlation coefficient ' $r$ ' ranges between -1.0 to +1.0 . the closer the value is to 1 or -1 , the stronger the relationship between the two variables. According to table 4.21, $r=0.808$. These result shows that there is a moderate positive relationship between $E$ satisfaction and online purchase intention of Gen Y.

\section{Correlations}

\begin{tabular}{llr|r} 
& & & brandinten \\
& & $\mathrm{t}$ & purchint \\
\hline \multirow{2}{*}{$\begin{array}{l}\text { brandinten } \\
\mathrm{t}\end{array}$} & $\begin{array}{l}\text { Pearson } \\
\text { Correlation }\end{array}$ & 1 & $.823^{* *}$ \\
\cline { 2 - 4 } & Sig. (2-tailed) & & \\
\cline { 2 - 4 } & $\mathrm{N}$ & 400 & .000 \\
\hline purchint & $\begin{array}{l}\text { Pearson } \\
\text { Correlation }\end{array}$ & $.823^{* *}$ & 1 \\
\cline { 2 - 4 } & Sig. (2-tailed) & .000 & \\
\cline { 2 - 4 } & $\mathrm{N}$ & 400 & 400 \\
\hline **. Correlation is significant at the 0.01 level (2-tailed).
\end{tabular}

Table 4.22 Correlation result of Brand Involvement (Source: Researchers own analysis)

The strength of the relationship between two variables which are Brand Involvement and online purchase intention of Generation Y. Were measured using Pearson's Correlation Coefficient. Based on table 4.22, the significant value ( $p$-value) is 0.000 . Thus, this shows that the correlation between Brand involvement and online purchase intention of Generation $Y$ is 
significant. Besides that, the correlation Coefficient ' $r$ ' ranges between -1.0 to +1.0 . According to table $4.22, r=0.823$. These results show that there is a moderate positive relationship between Brand involvement and online purchase intention of Generation Y.

\begin{tabular}{|c|c|c|c|}
\hline \multicolumn{4}{|c|}{ Correlations } \\
\hline & & techno & purchint \\
\hline \multirow[t]{4}{*}{ techno } & Pearson & 1 & $.838^{* *}$ \\
\hline & Correlation & & \\
\hline & Sig. (2-tailed) & & .000 \\
\hline & $\mathrm{N}$ & 400 & 400 \\
\hline \multirow[t]{3}{*}{ purchint } & $\begin{array}{l}\text { Pearson } \\
\text { Correlation }\end{array}$ & $.838^{* *}$ & 1 \\
\hline & Sig. (2-tailed) & .000 & \\
\hline & $\mathrm{N}$ & 400 & 400 \\
\hline
\end{tabular}

**. Correlation is significant at the 0.01 level (2tailed).

Table 4.23: Correlation result of Technology

(Source: Researchers own analysis)

Pearson's Correlation Coefficient was used to measure the strength of the relationship between two variables which are Technology and online purchase intention of Generation Y. Based on table 4.23 , the significance value $(p)$ is 0.000 . This indicates that the correlation between Technology and online purchase intention of Generation $Y$ is significant.

Besides that, the Correlation Coefficient ' $r$ ' ranges between -1.0 to +1.0 . According to table 4.23, $r=0.838$, these results show that there is a moderate positive relationship between Technology and online purchase intention of Generation Y.

\begin{tabular}{|c|c|c|c|}
\hline \multicolumn{4}{|c|}{ Correlations } \\
\hline & & locat & purchint \\
\hline \multirow[t]{3}{*}{ locat } & $\begin{array}{l}\text { Pearson } \\
\text { Correlation }\end{array}$ & 1 & $.817^{* *}$ \\
\hline & Sig. (2-tailed) & & .000 \\
\hline & $\mathrm{N}$ & 400 & 400 \\
\hline \multirow[t]{3}{*}{ purchint } & $\begin{array}{l}\text { Pearson } \\
\text { Correlation }\end{array}$ & $.817^{* *}$ & 1 \\
\hline & Sig. (2-tailed) & .000 & \\
\hline & $\mathrm{N}$ & 400 & 400 \\
\hline
\end{tabular}

Table 4.24: Correlation result of Location

(Source: Researchers own analysis)

Pearson's correlation coefficient was used to measure the strength of the relationship between two variables which are Location and online purchase intention of Generation Y. 
based on table 4.24 the significance value ( $p$-value) is 0.000 . This indicates that the correlation between Location and online purchase intention of Generation $Y$ is significant.

Besides that, the correlation coefficient ' $r$ ' ranges between -1.0 to +1.0 . the closer the value is to 1 or -1 , the stronger the relationship between the two variables. According to table 4.24, $r=0.817$, these result shows that there is a moderate positive relationship between Location and online purchase intention of Generation $\mathrm{Y}$.

Regression analysis

\subsubsection{Table 4.25: Model Summary}

\begin{tabular}{ll|r|r|r} 
Model & $\mathrm{R}$ & R Square & $\begin{array}{c}\text { Adjusted R } \\
\text { Square }\end{array}$ & $\begin{array}{c}\text { Std. Error of } \\
\text { the Estimate }\end{array}$ \\
\hline 1 & $.879^{\mathrm{a}}$ & .773 & .772 & .26071 \\
\hline
\end{tabular}

a. Predictors: (Constant), techno, esatsmean, brandin

(Source: Primary data from output SPSS)

Based on table 4.25 the correlation coefficient of $\mathrm{R}=0.879$ indicates that there is a positive relationship between dependent variable Purchase intention and the independent variables which are E-Satisfaction, Brand involvement and Technology. Meanwhile the coefficient of determination, $\mathrm{R}$ Square $=0.773$. this indicated that $77.3 \%$ of the total variation in online purchase intention of Generation $Y$ was explained by three predictors (E-satisfaction, Brand involvement and Technology). However, the remaining $22.7 \%$ will be explained by other factors besides E-satisfaction, Brand involvement and Technology.

\subsubsection{Table 4.26: ANOVA $^{a}$}

\begin{tabular}{|c|c|c|c|c|c|c|}
\hline Model & & $\begin{array}{c}\text { Sum of } \\
\text { Squares }\end{array}$ & $d f$ & $\begin{array}{c}\text { Mean } \\
\text { Square }\end{array}$ & $\mathrm{F}$ & Sig. \\
\hline \multirow[t]{3}{*}{1} & Regression & 91.846 & 3 & 30.615 & 450.419 & $.000^{b}$ \\
\hline & Residual & 26.916 & 396 & .068 & & \\
\hline & Total & 118.762 & 399 & & & \\
\hline
\end{tabular}

a. Dependent Variable: purchint

b. Predictors: (Constant), techno, esatsmean, brandintent

(Source: Primary data from output SPSS)

Based on table 4.26 Annova, the $F$ value of 450.419 is significant at $p=0.000(p<0.05)$. Therefore, it shows that the independent variables Technology, E-Satisfaction and Brand involvement statistically significantly predict the dependent variable Purchase intention, $\mathrm{F}(3$, $396)=450.419, p<0.05$. Thus, it can be deduced that the regression model is a good fit of the data. 


\subsubsection{Table 4.27: Coefficients ${ }^{\mathrm{a}}$}

\begin{tabular}{|c|c|c|c|c|c|c|c|}
\hline \multirow[b]{2}{*}{ Model } & \multicolumn{2}{|c|}{$\begin{array}{l}\text { Unstandardized } \\
\text { Coefficients }\end{array}$} & \multirow{2}{*}{$\begin{array}{c}\text { Standardize } \\
d \\
\text { Coefficients } \\
\text { Beta }\end{array}$} & \multirow[b]{2}{*}{$\mathrm{t}$} & \multirow[b]{2}{*}{ Sig. } & \multicolumn{2}{|c|}{ Collinearity Statistics } \\
\hline & B & Std. Error & & & & Tolerance & VIF \\
\hline (Constant) & .113 & .118 & & .950 & .343 & & \\
\hline esatsmean & .252 & .048 & .240 & 5.230 & .000 & .272 & 3.677 \\
\hline brandintent & .310 & .047 & .308 & 6.585 & .000 & .262 & 3.810 \\
\hline techno & .409 & .049 & .390 & 8.360 & .000 & .263 & 3.799 \\
\hline
\end{tabular}

a. Dependent Variable: purchint

(Source: Primary data from output SPSS)

According to table $4.27 \mathrm{p}$ value is lower than $0.05(\mathrm{p}<0.05)$ it is considered that there is a significant relationship between independent value (ESAT, BI and Technology) and dependent value (Purchase intention). Therefore, $T$ value greater than or equal to 4 , from this table independent values all higher than 4 therefore it is significant.

Besides that, the Tolerance range $<1.0$, while VIF lower than 5. According to table 4.27, all items lower than 1 and 5, these results show that there is a positive relationship between independent values (ESAT, BI and Technology) and dependent value online purchase intention of Generation Y.

Hypothesis Testing

Hypothesis 1

HO: There is no significant relationship between E-Satisfaction and online purchase intention of Generation Y

$\mathrm{H} 1$ : There is significant relationship between E-Satisfaction and online purchase intention of Generation $Y$

Reject $\mathrm{HO}$ if $\mathrm{p}<0.05$

Based on table 4.27 linear regression, the significant value for convenience is 0.000 which is less than $\mathrm{p}$-value of 0.05 . Thus, $\mathrm{HO}$ is rejected while $\mathrm{H} 1$ is accepted. This explains that there is a significant relationship between E-satisfaction and online purchase intention of Generation Y.

Hypothesis 2

HO: There is no significant relationship between Brand involvement and online purchase intention of Generation $Y$

$\mathrm{H} 2$ : There is significant relationship between Brand involvement and online purchase intention of Generation Y.

Reject $\mathrm{HO}$ if $\mathrm{p}<0.05$

Based on table 4.27 linear regression the significant value for Brand involvement is 0.000 which is less than p-value of 0.05 . Thus, $\mathrm{HO}$ is rejected while $\mathrm{H} 2$ is accepted. This explains that there is a significant relationship between Brand involvement and online purchase intention of Generation Y.

Hypothesis 3

Ho: There is no significant relationship between Technology and online purchase intention of Generation Y 
H3: There is significant relationship between Technology and online purchase intention of Generation $Y$

Reject $\mathrm{HO}$ if $\mathrm{p}<0.05$

Based on table 4.27 linear regression, the significant value for TAM is 0.000 which is less than $\mathrm{p}$-value of 0.05 . Thus, $\mathrm{Ho}$ is rejected while $\mathrm{H} 3$ is accepted. This explains that there is a significant relationship between TAM and online purchase intention of Generation Y.

Hypothesis 4

HO: Location has not moderating effect on between e-satisfaction and purchase intention of Generation $Y$

$\mathrm{H} 4$ : Location has moderating effect on between e-satisfaction and purchase intention of Generation Y

\begin{tabular}{lrrrrrr} 
Model & \multicolumn{1}{c}{} & $\mathrm{p}$ & LLCI & ULCI \\
constant & 4.4185 & .0173 & 255.3015 & .0000 & 4.3845 & 4.4525 \\
esatsmea & .4558 & .0443 & 10.2865 & .0000 & .3687 & .5429 \\
locat & .4981 & .0447 & 11.1470 & .0000 & .4102 & .5859 \\
Int_1 & .0203 & .0472 & .4298 & .6676 & -.0724 & .1130
\end{tabular}

Table 4.28: Moderating model summary between ESAT and PI

According to table 4.28 the significant value for ESAT is 0.6676 which is higher than $p$ value $=0.05$. Therefore, $\mathrm{H} 4$ is rejected while $\mathrm{HO}$ is accepted. This explains that location has not moderating effect on between ESAT and Purchase intention.

Hypothesis 5

HO: Location has not moderating effect on between brand involvement and purchase intention of Generation Y

H5: Location has moderating effect on between brand involvement and purchase intention of Generation Y

\begin{tabular}{lrrrrrr} 
Model & \multicolumn{7}{c}{} & & & \\
& coeff & se & $\mathrm{t}$ & $\mathrm{p}$ & LLCI & ULCI \\
constant & 4.4125 & .0164 & 269.6234 & .0000 & 4.3803 & 4.4447 \\
brandint & .4852 & .0392 & 12.3610 & .0000 & .4080 & .5623 \\
locat & .4764 & .0412 & 11.5694 & .0000 & .3955 & .5574 \\
Int_1 & .0475 & .0428 & 1.1080 & .2685 & -.0368 & .1317
\end{tabular}

Table 4.29: Moderating model summary between $\mathrm{BI}$ and $\mathrm{PI}$

Base on table 4.30 the significant value for $\mathrm{BI}$ is 0.2685 which is higher than $\mathrm{p}$ value $=0.05$. Therefore, $\mathrm{H} 5$ is rejected while $\mathrm{HO}$ is accepted. This explains that location has not moderating effect on between brand involvement and Purchase intention.

Hypothesis 6

HO: Location has not moderating effect on between technology and purchase intention of Generation Y

H6: Location has moderating effect on between technology and purchase intention of Generation $Y$ 


\begin{tabular}{|c|c|c|c|c|c|c|}
\hline & coeff & se & $t$ & $\mathrm{p}$ & LLCI & ULCI \\
\hline constant & 4.4212 & .0175 & 252.3728 & .0000 & 4.3867 & 4.4556 \\
\hline techno & .5418 & .0498 & 10.8903 & .0000 & .4440 & .6396 \\
\hline locat & .3992 & .0495 & 8.0577 & .0000 & .3018 & .4966 \\
\hline Int_1 & .0073 & .0468 & .1563 & .8759 & -.0848 & .0994 \\
\hline
\end{tabular}

Table 4.30: Moderating model summary between Technology and PI Table 31 shows the significant value for Technology is 0.8759 which is higher than $p$ value $=0.05$. Therefore, $\mathrm{H} 6$ is rejected while $\mathrm{HO}$ is accepted. This explains that location has not moderating effect on between Technology and Purchase intention.

\section{Chapter Summary}

Chapter 4 has been conducted by using SPSS version 23. The respondents 'general information and demographic profile have been described by descriptive analysis. In addition, the collected data has been measured in the central tendencies for independent variables and dependent variable. Furthermore, the reliability test has been conducted to check on the reliability of the variables. Next, Pearson Correlation Analysis, Multiple Regression Analysis and the test of hypotheses have been explained in this chapter. Lastly, further discussion and findings will be carried out in the following chapter.

\section{Discussion and Conclusion}

Discussion of the Study

The general objective of this study was to investigate the relationship between e-satisfaction, brand involvement, technology and purchase intention among generation y in Klang valley. The first objective of the study was to determine the dimensions of e-satisfaction that influence purchase intention. The second research objective was to relationship between brand involvement and purchase intention. The third research objective was to examine the relationship between technology and purchase intention. The study determined the existence of a significant positive relationship between independent variables (e-satisfaction, brand involvement, technology) and dependent variable (purchase intention). The fourth study noted that there is no significant relationship between e-satisfaction and purchase intention for an examination of the moderated relationship. The fifth objective which also marked the initial step of testing for moderating sought to establish the relationship between brand involvement and purchase intention. It was observed that brand involvement has no significantly influenced location. The last objective was to assess the extent to which location moderates the relationship between technology and purchase intention. It was established that location has no moderating the relationship between technology and purchase intention.

Implication of the Findings

In order to gain online shopping market, it is important to understand the factors that influence consumers' e-shopping satisfaction that contribute to purchase intention of generation $y$. This research study tried to provide depth measurement and understand the antecedents of e-satisfaction, brand involvement, technology on online purchase intention moderated by location. Based on the research findings, several implications will be provided for online purchase intention of generation $y$. 
Implications for Online shopping Marketers

This research study has suggested the following implications for online shop marketers. Firstly, this study suggested online shopping marketers should enhance their marketing strategy in website development, brand choice experiential because the results indicated technology and brand involvement had the significant relationship towards generation y's online shopping satisfaction and also had the direct impact on generation y's purchase intention. Online shopping marketers should target on hedonic dominant aspects, create the high quality of website content in order to generate fun and excitement to online consumers since interesting and developed website and brand choice and design has the most important factor to influence e-shopping satisfaction and online shopping purchase intention ( $\mathrm{Ha} \&$ Stoel, 2012). Meanwhile, online consumers very sensitive on fraud of transaction and misuse of personal information issues therefore enhancement of online security systems is essential in order to protect privacy of personal information and safety of transaction.

Second, website design cannot be underestimated although it has the least impact on eshopping satisfaction. Website design is an important instrument to provide consumers ease of use and usefulness during online transaction processes (Lee $\&$ Lin, 2005). Online shop marketers still need to always pay attention to ensure website design is readable and tidy, easy to locate information and have clear product information. Third, customer service cannot be ignored although insignificantly related to e-shopping satisfaction. Customer service still consider play an important role because it has direct influence on consumers' online shopping purchase intention therefore online shopping marketers still need to ensure customer service provided is able to meet the expectation of customers.

\section{Research Contributions}

The study is going to have enormous contributions to the generation y in Klang valley. In this study findings shows that generation y purchase online shopping basing on satisfaction and service quality/technology and involvement of the brand/product. This information got from online shopping experienced generation y. Online websites have to pay attention their service quality, online payment towards on generation y satisfaction so as to have a higher margin of consumer.

For generation y base on satisfaction they will repurchase from the first website base on high speed technology, real information about product (size, colour etc), service and fast delivery therefore, generation y can jump to any website if they are not satisfying with the first purchase for online shopping. Because they are good in technology therefore, they would buy whatever they want because of brand/product involvement.

Therefore, future research might consider developing and discovering more factors or predictors and antecedents to allow richer coverage online shopping purchase intention of generation y. Moreover, future research may replicate and elaborate more scale measurement of e-satisfaction, brand involvement, technology and purchase intention moderated by location to observe different findings across different culture, ethnicity and cover more segment of online shopping industry.

\section{Research Recommendations}

Based on the research findings, the results of this study can provide valuable insights for online websites or retailers to make improvement in order to hold and maintain the high profitability relationship with the consumers. There were several recommendations that can be considered based on the findings of this research. Firstly, e-satisfaction, brand 
involvement, technology has found to have high positive influence on purchasing intention of generation $\mathrm{y}$. This highlights the importance of generating and maintaining a positive and attractive e-satisfaction and technology among online website. Future studies can focus on areas such as increase satisfaction, develop website and also to investigate further into the various factors that form a positive brand involvement and e-satisfaction among consumers. Besides that, in this research, it is concluded that location has not moderating effect on between independent variables (e-satisfaction, brand involvement, technology) and dependent variable (purchase intention). The results however should not be used to dismiss the relationship between independent variables and purchase intention in generation y. As e-satisfaction, brand involvement, and technology may consist of different aspects and multiple degrees of variances, future research can focus on analysing the various aspect of location to further investigate which of the aspects may have an influence on the various consumption behaviours of the consumers. Based on this research, there were several recommendations for the future researchers to make improvement of the limitations of this study. First, future researchers are encouraged to design questionnaires in multilingual besides the English language in order to target respondents that are not familiar with the English language. This may overcome the limitations of potential respondents being unable to participate in this research due to limited proficiency of the English language. In order to gain different insights about the same area of research, future researchers are encouraged to duplicate this study into another region or country besides Klang Valley. This is a good opportunity for researchers to understand the consumers' buying behaviour aside from consumers from the Klang Valley area. Future researchers are encouraged to use different a set of variables to study this area of research can gain different results and understand the target populations' buying behaviours in a different angle.

Research Limitation

In this study location has no moderating effect on e-satisfaction and purchase intention, brand involvement and purchase intention and between technology and purchase intention has no moderation by location. Ilian and Yasuo (2005) defined location as the choice mode of entering business. Also, Kala et al., (2010) defined location as choice of where a business is to be located which could be small, medium and large cities or urban or rural locations. this definition is in line with Esteban, Yancy and Christian (2010) referred to location as a choice of locating your business either in the rural or urban centre which is also link with the type of product or service the firm tend to offered. Location is an indispensable factor that shapes and determines the success or failure of entrepreneurial development and business activities. Thus, it determines the effectiveness of the entrepreneurial and business activities. The inconsistent findings also indicate that some important variables such as location have not been considered in the previous studies. This present study proposes that location would moderate the relationship between e-satisfaction, brand involvement, technology and purchase intention. Hence, it provides the indirect test of the various relationships indicated in this study through the applicability of hierarchical regression analysis. From the results of the moderating model, it was found that location has no moderating effect on e-satisfaction, brand involvement, technology and purchase intention. Although, much evidence is not available to support the no moderating influence of location on the relationship between esatisfaction and purchase intention. For instance, Orloff (2002) has asserted that location play a very vital role in the development of entrepreneurship which also include the small of firms. However, the insignificant of location within this context, does not down play the role of 
location factor in the success of online purchase intention. The inconsistent findings also indicate that some important variables such as location have not been considered in the previous studies. Additionally, the cause of this insignificant of location in this relationship might be due to different factor and variables in the study. This result suggest that location is not a suitable variable for online purchase intention. However, the most important factor of entrepreneurship and business development is the strategical location of the business which could include the nearness to raw material, accessibility to business premises, good rod network, busyness of the area of the business etc. Location should be seen as a separate factor that should be merged with the external factor. This result shows that location is not a moderating factor that influence between e-satisfaction, brand involvement, technology and purchase intention.

The findings of the moderating effect of location as seen in table 4.28, 4.29 and 4.30 is evidence to show that there is no relationship between e-satisfaction and purchase intention, brand involvement and purchase intention, technology and purchase intention. With this stated, there would be need to further this research by choosing another moderating variable in line with the context of the research. The contribution of this study would be very visible in the body of literature in the academic field of online purchase intention since this study would become the first study to investigate location as a moderating variable in the relationship between independent variables and dependent variable in generation y.

\section{Conclusion}

This study was conducted to provide in-depth investigation on factors that influence generation y's purchase intention on online shopping. This research project had achieved the objectives to identify the variables or predictors of online shopping quality and examine the relationship towards online shopping outcomes (e-satisfaction and purchase intention). Therefore, the findings of this this study is supported Oliver's (1997) quality - satisfaction behavioural intention link model. Meanwhile, findings of this study also indicated that esatisfaction, brand involvement, technology had direct relationship to online shopping purchase intention of generation y.

As a conclusion, the outcome of this research project indicated that e-satisfaction is the most important factor to influence online shopping purchase intention of generation y. Although e-satisfaction is the strongest impact on online shopping purchase intention other factors such as brand involvement and technology should not be underestimated. In addition, implication, limitation and recommendations for future studies have been provided in this study as a guideline for online retailers to develop innovative online marketing strategy and reference for future research to find out more coverage of online shopping purchase intention dimensions across the different retail segment, culture and ethnic.

\section{References}

Abishek \& Henchand, S. (2016), 'Adoption of Sensor Based Communication for Mobile Marketing in India', Journal of Indian Business Research, Vol. 8, No. 1, pp. 65-76.

Ahmad, S., Xavier, S., \& Bakar, A. (2014). Examining entrepreneurial intention through cognitive approach using Malaysia GEM data. Journal of Organizational Change Management, 27(3), 449-464. http://dx.doi.org/10.1108/jocm-03-2013-0035

Aksoy, L., Van Riel, A., Kandampully, J., Bolton, R. N., Parasuraman, A., Hoefnagels, A., Migchels, N., Kabadayi, S., Gruber, T., Loureiro, Y. K., and Solnet, D. (2014). 
Understanding Generation $Y$ and their use of social media: a review and research agenda. Journal of service management.

Algharabat, R., Alalwan, A. A., Rana, N. P., and Dwivedi, Y. K. (2017). Three-dimensional product presentation quality antecedents and their consequences for online retailers: The moderating role of virtual product experience. Journal of Retailing and Consumer Services, 36, pp.203-217

Apadula, L. T., and Predmore, C. E. (2019). The Shift to "Social": Social and Commercial Entrepreneurship Must Meld to Meet Changing Consumer Preferences. Journal of Management Policy and Practice, 20(1).

Astuti, B., \& Putri, A. P. (2018). Analysis on the Effect of Instagram Use on Consumer Purchase Intensity. Review of Integrative Business and Economics Research, 7, 24-38.

Azam, A. (2015). Investigation of psychological dimensions of trust on e-loyalty. Journal of Islamic Marketing, 6(2), 224-249. http://dx.doi.org/10.1108/jima-12-2013-0083

Azam, A., Qiang, F., Abbas, S., \& Abdullah, M. (2014). Structural equation modelling (SEM) based trust analysis of Muslim consumers in the collective religion affiliation model in e-commerce. Journal of Islamic Marketing, 4(2), 134-149. http://dx.doi.org/10.1108/17590831311329278

Bachleda, C., and Selmouni, Y. (2014). E-satisfaction: A Moroccan replication and extension. Services Marketing Quarterly, 35(3), pp.270-287.

Bełcik A. (2017), Carrefour otworzył sklep w stylu omnichannel, www.pb.pl/carrefourotworzyl-sklep-w-trendzie-omnichannel-901204, accessed: 4.02.2018.

Brown, T.A., 2015. Confirmatory factor analysis for applied research. Guilford publications.

Carlson, J., O'Cass, A., and Ahrholdt, D. (2015). Assessing customers' perceived value of the online channel of multichannel retailers: A two country examination. Journal of Retailing and Consumer Services, 27, pp.90-102.

Chaffey, D. (2015). Forecast growth in percentage of online retail/ecommerce sales [\#Digitallnsights]. Retrieved from https://www.smartinsights.com/digital-marketingstrategy/online-retail-sales-growth/ [Google Scholar]

Ordun. (2015). Millennial (Gen Y) Consumer Behavior, Their Shopping Preferences and. Canadian Social Science, 11(4), 40-55.

Chen, Y., Wu, J., \& Chang, H. (2014). Examining the mediating effect of positive moods on trust repair in ecommerce. Internet Research, 23(3), 355-371. http://dx.doi.org/10.1108/10662241311331772

Chi, A. Y. Y., Chee, C. M., Cheng, C. F., and Von, T. Y. (2014). Factors Influencing Generation Y 'S Online Purchase Intention in Book Industry (Doctoral dissertation, UTAR).

Chiu, C. M., Wang, E. T., Fang, Y. H., and Huang, H. Y. (2014). Understanding customers' repeat purchase intentions in $\mathrm{B} 2 \mathrm{C}$ e-commerce: the roles of utilitarian value, hedonic value and perceived risk. Information Systems Journal, 24(1), pp.85-114.

Chu, P. Y., Lee, G. Y., and Chao, Y. (2012). Service quality, customer satisfaction, customer trust, and loyalty in an e-banking context. Social Behavior and Personality: an international journal, 40(8), pp.1271-1283.

Dabija, D. C., and Grant, D. B. (2016). Investigating shopping experience and fulfilment in omnichannel retailing: A proposed comparative study in Romania and UK of generation $Y$ consumers. In Proceedings of the 21st Annual Logistics Research Network (LRN) Conference, University of Hull, September, e-proceedings.

De Oña, J., De Oña, R., Eboli, L., and Mazzulla, G. (2013). Perceived service quality in bus transit service: a structural equation approach. Transport Policy, 29, pp.219-226. 
Difference between traditional commerce and e-commerce. Retrieved 31 May, 2018, from Key Differences: https://keydifferences.com/differencebetween-traditionalcommerce-and-e-commerce.html

Dost, B., Illyas, M., \& Rehman, C. A. (2015). Online shopping trends and its effects on consumer buying behaviour: A case study of young generation of Pakistan. NG-Journal of Social Development, 417(3), 1-22.

Dhanapal, S., Vashu, D., and Subramaniam, T. (2015). Perceptions on the challenges of online purchasing: a study from "baby boomers", generation " $X$ " and generation " $Y$ " point of views. Contaduría y Administración, 60, pp.107-132.

El-Adly, M. I., and Eid, R. (2016). An empirical study of the relationship between shopping environment, customer perceived value, satisfaction, and loyalty in the UAE malls context. Journal of Retailing and Consumer Services, 31, pp.217-227.

Epsilon (2015), Digital Shopping Tool Impact Study 2015, https://retailnet.pl/2015/07/27/13611-raport-wplyw-mediow-spolecznosciowych-inarzedzi-mobilnych-w-procesie-zakupowym/, accessed: 30.01.2017.

Fernie, J., \& Grant, D. B. (2015), Fashion Logistics, Kogan Page: London.

Gabriel, J. M. O., Ogbuigwe, T. D., \& Ahiauzu, L. U. (2016). Online shopping systems in Nigeria: Evolution, trend and prospects. Asian Research Journal of Arts and Social Sciences 1(4) 1-7.

Gupta, D. C., Bindal, M., Agarwal, N., \& Khandelwal, K. (2018). Traditional commerce v/s ecommerce and impact of demonetization on e-commerce. International Journal of Engineering and Management Research, 8(2), 136-142.

Hinson, R. E., Anning-Dorson, T., \& Kastner, A. A. N. A. (2014). Consumer attitude towards shopping malls in Sub-Saharan Africa: an exploration of the "new" retail format in Ghana. African Journal of Business and Economic Research, 7(2-3):97-134.

Homewood S. (2015), OMD and NewsLifeMedia team up to target millennials, www.adnews.com.au/news/omd-and-newslifemedia-team-up-to-target-millennials, accessed: 2.02.2018.

Howlader, M. (2015). Customer service satisfaction survey of e-commerce sites in Finland. Cited 12.2.2017 https://oamk.finna.fi/Record/leevi.180658

Hussein, Z. (2017). Leading to intention: The role of attitude in relation to technology acceptance model in e-learning. Procedia Computer Science, 105, pp.159-164.

Ilian, P. S., and Yasuo, H. (2015). Influence of location factors on establishment and ownership of foreign investments: The case of the Japanese manufacturing firms in Europe. International business review, 14(5), pp.577-598.

Internet World Stats. (2017). Internet usage statistics. The internet big picture world internet users and 2017 population stats. Retrieved from http://www.internetworldstats.com/stats.htm. [Google Scholar]

Issa, T., Isaias, P. and Kommers, P., 2016. The impact of smart technology on users and society. Jiang, L., Yang, Z., \& Jun, M. (2013). Measuring consumer perceptions of online shopping convenience. Journal of Service Management, 24(2), 191-214

Jones, S., \& Fox, S. (2014). Generations online in 2009. Pew Internet \& American Life Project. http://www.pewinternet.org/2009/01/28/generations-online-in-2009/

Kudeshia, C., \& Kumar, A. (2017). Social eWOM: does it affect the brand attitude and purchase intention of brands. Management Research Review, 40(3), 310-330. 
Kumar, M. (2016). Consumer Behavior and Satisfaction in E-Commerce: A Comparative Study Based on Online Shopping of Some Electronic Gadgets. International Journal of Research in Commerce \& Management Vol. 7 No. 07 (July) ISSN 0976-2183

Krejcie, R. V., and Morgan, D. W. (1970). Determining sample size for research activities. Educational and psychological measurement, 30(3), pp.607-610.

Leong, A. M. W., Yeh, S. S., Hsiao, Y. C., and Huan, T. C. T. ( 2015). Nostalgia as travel motivation and its impact on tourists' loyalty. Journal of Business Research, 68(1), pp.81-86.

Lindh, C., Rovira Nordman, E., Melén Hånell, S., Safari, A., and Hadjikhani, A. 2020. Digitalization and International Online Sales: Antecedents of Purchase Intent. Journal of International Consumer Marketing, pp.1-12.

Li, D., Wang, C. L., Jiang, Y., Barnes, B. R., and Zhang, H. (2014). The asymmetric influence of cognitive and affective country image on rational and experiential purchases. European Journal of Marketing.

Martin, C. A., \& Turley, L. W. (2014). Malls and consumption motivation: an exploratory examination of older Generation $Y$ consumers. International Journal of Retail \& Distribution Management, 32(10):464-475

Mayayise, T., \& Osunmakinde, I. (2014). E-commerce assurance models and trustworthiness issues: an empirical study. Information Management \& Computer Security, 22(1),

76-96. http://dx.doi.org/10.1108/imcs-01-2013-0001

Mindshare Polska. (2015), Multiscreening, www.wirtualnemedia.pl/artykul/multiscreeningpowszechny-wsrod-internautow-w-gore-shifting-infografika, accessed: 2.02.2018

Mitchell, V. W., Bakewell, C., Jackson, P., and Heslin, C. (2015). How message framing affects consumer attitudes in food crises. British Food Journal.

Mittal, B., \& Lee, M. (1989). A causal model of consumer involvement. Journal of Economic Psychology, 10(3), 363-389.

Moolman, H. J. (2011). Restaurant customer satisfaction and return patronage in a Bloemfontein shopping mall. Acta Commercii, 11:129-146.

Naim, M. F., and Lenkla, U. (2016). Knowledge sharing as an intervention for Gen Y employees' intention to stay. Industrial and Commercial Training.

Nielsen Company. (2012). African-American consumers: Still vital, still growing 2012 report. http://www.nielsenkorea.com/comm/reports/AfricanAmericanConsumers\%20Still\%2 OVital\%20Still\%20Growing \%202012\%20Report_FINAL.pdf

Noble, S. M., Haytko, D. L., \& Phillips, J. (2009) . What drives college-age Generation Y consumers? Journal of Business Research, 62(6):617-628.

Nurhasanah, S., and Hariyani, H. (2018). Halal Purchase Intention on Processed

Food. Tazkia Islamic Finance and Business Review, 11(2)

Ou, C. X., Pavlou, P. A., and Davison, R. M. (2014). Swift guanxi in online marketplaces: The role of computer-mediated communication technologies. MIS quarterly, 38(1), pp.209230.

O'Donnell, J. (2006). Gen Y sits on top of consumer food chain. USA Today. http://usatoday30.usatoday.com/money/advertising/2006-10-11-retail-teensusat_x.htm

Oliver, R.L., 1999. Whence consumer loyalty? Journal of marketing, 63(4_suppl1), pp.33-44.

Osman, S., Chan, B. Y. F., \& Bei, H. C. (2010). Undergraduates and Online Purchasing Behaviour. Asian Social Science Vol. 6, No. 10, October 2010. [Online]. Available: 
http://www.ccsenet.org/journal/index.php/ass/article/viewFile/6351/5827 [2014, Feb 23].

Osman, S., Yin-Fah, B. C., and Hooi-Choo, B. (2010). Undergraduates and online purchasing behaviour. Asian Social Science, 6(10), p.133.Parasuraman, A., Grewal, D., \& Krishnan, R. (2007). Marketing Research. 2nd ed. Boston: Cengage Learning. [Google Scholar]

Parment, A. (2014). Marketing to the 90s generation: Global data on society, consumption, and identity. Springer.

Pawlasová, P., and Klézl, V. (2017). Factors affecting Generation Y Customers' Satisfaction with Online Group-Buying Purchases in South Korea. Acta Universitatis Agriculturae et Silviculturae Mendelianae Brunensis, 65(6), pp.2045-2054.

Phan, T. A., \& Mai, P. H. (2016). Determinants Impacting Consumers' Purchase Intention: The Case of Fast Food in Vietnam. International Journal of Marketing Studies, 8(5), 56-68.

Safari, A., \& Thilenius, P. (2013). Alleviating uncertainty through trust: A narrative approach to consumers' foreign online purchasing behaviour. Journal of Customer Behaviour, 12(2), 211-226. [Crossref], [Google Scholar]

Pilcher, J. (1994), 'Mannheim's sociology of generations: An undervalued legacy', British Journal of Sociology, Vol. 45, No. 3, pp. 481-495

PwC. (2017), Total Retail 2017, Jak przetrwać w cyfrowym świecie handlu, www.pwc.pl/pl/pdf/raport-total-retail-2017.pdf, accessed: 16.08.2017.

Rahman, S. M. (2015). Consumer expectation from online retailers in developing e-commerce market: An investigation of generation $Y$ in Bangladesh. International Business Research, 8(7), p.121.

Rares, A., and Jorie, R. J. (2015) . The effect of the price, promotion, location, brand image and quality products towards the purchase decision of consumers at Bengkel Gaoel Store Manado Town Square. Jurnal EMBA: Jurnal Riset Ekonomi, Manajemen, Bisnis dan Akuntansi, 3(2).

Reimann, M., and Aron, A. (2014). Self-expansion motivation and inclusion of brands in self: Toward a theory of brand relationships. In Handbook of brand relationships (pp. 87103). Routledge.

Refuel. (2015), Millenia teens digital explorer, http://research.refuelagency.com/wpcontent/uploads/2015/07/Millennial-Teen-Digital-Explorer.pdf, accessed: 1.02.2018

Robin, R. P. D. (2009). The Impact of Perceived Value on Purchase Intension. Consumer Behaviour Research on Online Shopping, 1-22.

San, L. Y., Omar, A., and Thurasamy, R. (2015), "Online purchase: a study of Generation Y in Malaysia", International Journal of Business and Management, Vol. 10 No. 6, pp. 1-7.

Salesforce blog 2015. 12 customer service tools that will make your customer's lives easier. Cited 6.2.2017

Saunders, M., Lewis, P., \& Thornhill, A. (2009). Research methods for business students (5th ed.). Prentice Hall: Financial Times.

Saunders, M., Lewis, P., and Thornhill, A. (2012). Research methods for business students (6. utg.). Harlow: Pearson.

Schaupp, L. C., and Bélanger, F. (2019). Social commerce benefits for small businesses: An organizational level study. In Social Entrepreneurship: Concepts, Methodologies, Tools, and Applications (pp. 1237-1255). IGI Global.

Sempruch-Krzemińska, K. (2014), Proces zakupu odzieży fast fashion, "Marketing i Rynek", nr 3 
Seo, J. I., and Namwamba, G. W. (2014). The investigation of product involvement in shopping behaviors among male college students. Atlantic Marketing Journal, 3(3), p.6.

Sethi, R. S., Kaur, J., and Wadera, D. (2018). Purchase intention Survey of Millennials towards online fashion stores. Academy of Marketing Studies Journal.

Setiowati, R., and Liem, Y. (2018). Impact of Packaging Design on Perceived Quality, Perceived Value, Brand Preference, and Repurchase Intention of Candy Products in Jakarta. Pertanika Journal of Social Sciences \& Humanities.

Sekaran, U., and Bougie, R. (2016). Research methods for business: A skill building approach. John Wiley \& Sons.

Siekierska, M. (2016), Omnichannel a multichannel. Którego podejścia potrzebuje twój sklep? www.payu.pl/blog/omnichannel-multichannel-ktorego-podejscia-potrzebuje-twojsklep, accessed: 2.02.2018.

Singh, D. P. (2015). Effect of shopping motivations on Indian consumers' mall patronage intention. Asia-Pacific Journal of Management Research and Innovation, 11(1):57-65

Singhi, A. D., McGrath, K., Brand, R. E., Khalid, A., Zeh, H. J., Chennat, J. S., Fasanella, K. E., Papachristou, G. I., Slivka, A., Bartlett, D. L. and Dasyam, A. K. (2018). Preoperative nextgeneration sequencing of pancreatic cyst fluid is highly accurate in cyst classification and detection of advanced neoplasia. Gut, 67(12), pp.2131-2141.

Sivanesan, R., Monisha, C., Babisha, V., \& Abisha, S. A. (2017). Comparative study on factors influencing online and traditional shopping. International Journal of Research in Management \& Business Studies, 4(3), 26-34

Shabib, F., and Ganguli, S. (2017). Impact of CSR on consumer behavior of Bahraini women in the cosmetics industry. World Journal of Entrepreneurship, Management and Sustainable Development.

Surbhi, S. (2016). Difference Between Traditional Commerce and e-Commerce. Key Differences, 15 Sept. 2016, key differences. com/difference-between-traditionalcommerce-and-e-commerce. html\# ixzz4 ynSOV8q8.

Shabib, F., \& Ganguli, S. (2017). Impact of CSR on consumer behavior of Bahraini women in the cosmetics industry. World Journal of Entrepreneurship, Management and Sustainable Development, 13(3), 174-203. [Crossref], [Web of Science ${ }^{\circledR}$ ], [Google Scholar]

Suprianto, D., Susanta, H., and Nurseto, S. (2014). The effect of product design, price and location toward purchase decision. Jurnal Ilmu Administrasi Bisnis. Vol. 3 No. 4.

Sznajder A. (2014), Technologie mobile w marketing, Wolters Kluwer, Warszawa.

Szulkowski T. (2016), Mobile w procesie zakupowym (cz. 1), http://nowymarketing.pl/a/11552,mobile-w-procesie-zakupowym-cz-1 , accessed: 16.08.2017.

Tan, K. W. (2018). Website Quality Social Activities and Online Purchase Intention in Malaysia (Doctoral dissertation, UTAR).

Tang, C., Mehl, M. R., Eastlick, M. A., He, W., and Card, N. A. (2016). A longitudinal exploration of the relations between electronic word-of-mouth indicators and firms' profitability: Findings from the banking industry. International Journal of Information Management, 36(6), pp.1124-1132.

Taylor, J. H., Xu, Y., Li, F., Shaw, M., Dziura, J., Caprio, S., Tamborlane, W. V., Nowicka, P., and Savoye, M. (2017). Psychosocial predictors and moderators of weight management programme outcomes in ethnically diverse obese youth. Pediatric obesity, 12(6), pp.453-461. 
Tiwari, R. K., \& Abraham, A. (2014'0. Understanding the consumer behavior towards shopping malls in Raipur city. International Journal of Management \& Strategy, 1(1):11- 21.

Thambiah, M. D., Nathan, S., Seow, B. Z., Liang, S., and Lingaraj, K. (2015). Patient satisfaction after total knee arthroplasty: an Asian perspective. Singapore medical journal, 56(5), p.259.

TNS Polska (2016). Marketing mobilny w Polsce 2016, www.tnsglobal.pl/coslychac/files/2015/05/POLSKA_JEST_MOBI_2015.pdf,accessed: 14.08.2017

Turak, N. (2015), The Millennial effect: how Generation $Y$ is shaping the way the world does business, www.fdiintelligence.com/Companies/The-Millennial-effect-how-GenerationY-is-shaping-the-way-the-world-does-business?ct=true, accessed: 12.08.2017.

Tseng, S. Y. (2016) . Bringing Enjoy Shopping by Using Credit Cards: The Antecedents of Internal Beliefs. Journal of Economics and Economic Education Research, 17(3), p.16.

Tsitsika, A., Janikian, M., Schoenmakers, T. M., Tzavela, E. C., Olafsson, K., Wójcik, S., Macarie, G. F., Tzavara, C., EU NET ADB Consortium and Richardson, C. (2014). Internet addictive behavior in adolescence: a cross-sectional study in seven European countries. Cyberpsychology, Behavior, and Social Networking, 17(8), pp.528-535.

Vaillant, Y., Lafuente, E., and Serarols, C. (2012). Location decisions of new 'Knowledge Intensive Service Activity'firms: The rural-urban divide. The Service Industries Journal, 32(16), pp.2543-2563.

Van Felius, N., Cavagnaro, E., and de Vries, M. (2018). The Impact of Third-Party Internet Sites on the Hotel Guest Journey.

Wagner, G., Schramm-Klein, H., \& Schu, M. (2016). Determinants and moderators of consumers' cross-border online shopping intentions. Marketing Zfp, 38(4), 214227. [Crossref], [Google Scholar]

Wang, Y. H., \& Tsai, C. F. (2014). The relationship between brand image and purchase

intention: Evidence from award winning mutual funds. The International Journal of Business and Finance Research, 8(2), 27-40.

Weeks, M. (2018). The Evolution and Design of Digital Economies.

Wedayanti, N., \& Giantari, I. (2016). Peran Pendidikan Kewirausahaan Dalam Memediasi Pengaruh Norma Subyektif Terhadap Niat Berwirausaha. E-Jurnal Manajemen Universitas Udayana, 5(1), 533-560

Slade, E., Dwivedi, Y., Piercy, N., \& Williams, M. (2015). Modeling consumers" adoption intentions of remote mobilepayments in the United Kingdom: extending UTAUT with innovativeness, risk, and trust. Psychology \& Marketing, 32(8), 860-873

Wee, C. S., Ariff, M. S. B. M., Zakuan, N., Tajudin, M. N. M., Ismail, K., \& Ishak, N. (2014). Consumers perception, purchase intention and actual purchase behavior of organic food products. Review of Integrative Business and Economics Research, 3(2), 378.

Williams, K., \& Page, R. (2014), 'Marketing to the Generations', Journal of Behavioural Studies in Business, Vol. 3, pp. 1-17

Yee, P. M., \&Heutger, M. (2015), 'Omni-Channel Logistics. A DHL Perspective on Implications and Use Cases for the Logistics Industry', Troisdorf, Germany: DHL Customer Solutions \& Innovation

Ramayah, \& Ignatius, J. (2010). Impact of Perceived usefulness, Perceived ease of use and Perceived. ICFAI Journal of Systems Management, 3(3), 36-51.

Yoon, Y., \& Uysal, M. (2005). An examination of the effects of motivation and satisfaction on destination loyalty: A structural model. Tourism Management, 26:45-56. 
Zendehdel, M., Paim, L. H., \& Osman, S. B. (2015). Students' online purchasing behavior in Malaysia: Understanding online shopping attitude. Cogent Business \& Management, 2(1), 1078428.

Zhang, R., Li, G., Wang, Z. and Wang, H. (2016). Relationship value based on customer equity influences on online group-buying customer loyalty. Journal of Business Research, 69(9), pp.3820-3826.

Zikmund, W. G. ( 2003). Sample designs and sampling procedures. Business research methods, 7(2), pp.368-400.

Jiang, Chun, \& Chih. (2008). Knowledge and Trust in E-consumers' Online Shopping Behavior. Electronic Commerce and Security, 2008 International Symposium on, 652-656. 